\title{
Applications of optimization techniques for parametric analysis of non-traditional machining processes: A Review
}

\author{
Shankar Chakraborty ${ }^{a^{*}}$, Bijoy Bhattacharyya ${ }^{a}$ and Sunny Diyaley ${ }^{b}$
}

${ }^{a}$ Department of Production Engineering, Jadavpur University, Kolkata, West Bengal, India

${ }^{b}$ Department of Mechanical Engineering, Sikkim Manipal Institute of Technology, Majitar, Sikkim, India

CHRON I C L E A B S T R A T

Article history:

Received: October 27, 2018

Received in revised format: November 28, 2018

Accepted: December 7, 2018

Available online:

December 7, 2018

Keywords:

Non-traditional machining pro-

cess

Response

Process parameter

Work material

Optimization

\begin{abstract}
The constrained applications of conventional machining processes in generating complex shape geometries with the desired degree of tolerance and surface finish in various advanced engineering materials are being gradually compensated by the non-traditional machining (NTM) processes. These NTM processes usually have higher procurement, maintenance, operating and tooling cost. Hence, in order to attain their maximum machining performance, they are usually operated at their optimal or near optimal parametric settings which can easily be determined by the application of different optimization techniques. In this paper, 133 international research papers published during 2012-16 on parametric optimization of NTM processes are extensively reviewed to have an idea on the selected process parameters, observed responses, work materials machined and optimization techniques employed in those processes while generating varying part geometries for their industrial use. It is observed that electro discharge machining is the mostly employed NTM process, applied voltage is the identified process parameter with maximum importance, surface roughness and material removal rate are the two maximally preferred responses, different steel grades are the mostly machined work materials and grey relational analysis is the most popular tool utilized for parametric optimization of NTM processes. These observations would help the process engineers to attain the machining performance of the NTM processes at their fullest extents for different work material and shape feature combinations.
\end{abstract}

\section{Introduction}

Difficulties in machining complicated and intricate shape features in varied hard-to-machine, highstrength-temperature-resistant materials, superalloys, metal matrix composites (MMCs) and other advanced engineering materials for aviation, nuclear power, wafer fabrication and automobile applications using conventional machining processes have caused to the evolution of an array of non-traditional machining (NTM) processes. In conventional material removal processes, like turning, milling, shaping, drilling etc., forces are applied on the workpiece with the help of a cutting tool to remove excess material in the form of chips. It induces plastic deformation within the workpiece leading to material removal due to shear action. On the other hand, in NTM processes, instead of employing sharp

\footnotetext{
* Corresponding author. Tel.: +9831568294 (M), +33-2548-2655 (R)

E-mail address: s chakraborty00@yahoo.co.in (S. Chakraborty)

(C) 2019 by the authors; licensee Growing Science, Canada doi: $10.5267 /$ j.msl.2018.12.004
} 
cutting tools, materials are removed using mechanical, thermal, electrical or chemical energy or combinations of them. In some of the NTM processes, the tool does not even make any contact with the workpiece, and it is also not mandatory that the tool material should have higher hardness than the work material. Basically, in NTM processes, material removal takes place from the workpiece surface in the form of minute particles while attaining superior surface smoothness and dimensional accuracy. These processes are generally classified based on the form of energy deployed for removal of material, i.e.:

a) Mechanical processes: Water jet machining (WJM), ultrasonic machining (USM), abrasive jet machining (AJM) etc.

b) Electrochemical processes: Electrochemical machining (ECM), electro jet drilling (EJD), electrochemical deburring (ECD) etc.

c) Electrical thermal processes: Electrical discharge machining (EDM), wire electrical discharge machining (WEDM), laser beam machining (LBM), electron beam machining (EBM) etc.

d) Chemical processes: Chemical machining (CHM), photochemical machining (PCM) etc.

e) Hybrid machining processes: Electrochemical grinding (ECG), electrochemical discharge machining $(\mathrm{ECDM})$, electrochemical honing $(\mathrm{ECH})$, abrasive water jet machining (AWJM), travelling wire electrochemical spark machining (TW-ECSM) etc.

These NTM processes have exceptionally low material removal rate (MRR) and consume excessive specific energy. Most of them have comparatively high procurement cost, tooling and fixture cost, power consumption and operating cost, and maintenance cost. Therefore, for productive and economic exploration of the capacities of NTM processes, their different machining/process parameters need to be optimally selected. Identification of the most relevant process parameters and their settings for any NTM process mainly depend on the expert knowledge and skill of the concerned operator. Sometimes, manufacturer's catalogues may also help in setting these parametric combinations to achieve the best machining performance. But, in most of the cases, these parametric combinations are conservative and depart from their optimal settings which cause hindrance in full exploitation of the capabilities of NTM processes. Selection of the optimal or near optimal parametric mix for different NTM processes thus becomes a vital decision making task. A variety of analytical techniques in the form of mathematical algorithms has been fruitfully employed for parametric optimization of NTM processes in order to fully explore their machining potentials and capabilities. At this very time, it now becomes essential to have an exhaustive investigation on the application and efficacy of various optimization techniques in determining the best parametric settings for different NTM processes.

In this paper, altogether 133 research papers published in different international journals during 201216 dealing with the applications of ECM, EDM, WEDM, LBM, USM and hybrid machining (HM) processes in real time manufacturing environment are extensively reviewed. This review mainly focuses on the identification of the type of work material used for the machining operation, machining parameters and responses chosen for the considered NTM processes, nature of the optimization problem developed and optimization technique(s) employed for achieving the best machining performance. The details of this analysis for the six above-mentioned NTM processes are presented here-in-under.

\subsection{ECM process}

The first machining process similar to ECM was patented by Gusseff in 1929, and its successful commercial application was started in late 1950s and early 1960s in aerospace and other manufacturing industries to perform shaping and finishing operations. It is a carefully regulated anodic dissolution process to shape the workpiece (anode) using a tool (cathode), approaching towards the workpiece with a constant feed rate. The electrolyte $\left(\mathrm{NaCl}, \mathrm{NaNO}_{3}\right)$ flowing at high speed through the inter-electrode gap usually removes the dissolved metal from the machining zone. Between the pre-shaped cathode tool and the anode workpiece, a DC voltage (10-25 V) is applied, causing atomic level reactions to take 
place within the electrolytic medium which is mainly responsible for removal of metal from the workpiece to achieve its desired shape. The final workpiece shape thus becomes an approximate negative mirror copy of the tool electrode (Rajurkar et al., 1999).

In ECM process, as the mechanical or physical properties of the work material do not influence the material removal mechanism, it can machine different electrically conductive materials regardless of their hardness, toughness or thermal characteristics. Almost all kinds of metal, including high-alloyed nickel, titanium-based alloys, superalloys and MMCs, can be efficiently machined using this process. It has several advantages, like no tool wear, high MRR, good surface finish, no need for deburring operation, and capability of generating complex shape geometries (contours, ring ducts, grooves etc.) for subsequent use in aerospace, automotive, defense and medical industries. Nowadays, it is also being successfully utilized in micro-machining and fabrication (dimensions within 1-999 $\mu \mathrm{m}$ ) of engineering components (Bhattacharyya et al., 2002). For achieving maximum benefits from this machining system, its different process parameters can be selected as applied voltage, current, electrolyte temperature, electrolyte flow rate, electrolyte concentration, inter-electrode gap and tool material (copper, brass or bronze) (Senthilkumar et al., 2013). In view of difficulties encountered from the conventional machining processes, like high tool wear and high tooling cost, this process now proffers an effective alternative to fulfill the requirements of the machining personnel.

Table 1 exhibits the details of the research works executed during 2012-16 on parametric optimization of ECM processes. It mainly includes various control parameters and responses selected for ECM operation, type of the work material considered for this process and optimization technique(s) adopted for its parametric optimization. The analysis of this information is graphically represented in Fig. 1. From this figure, it can be revealed that among various machining parameters of ECM process, applied voltage is the most important one, followed by tool feed rate, electrolyte flow rate, electrolyte concentration and inter-electrode gap. With respect to the responses, MRR is provided with the maximum importance, followed by surface roughness and radial overcut. Among the chosen work materials, various grades of steel are maximally machined using ECM processes, followed by different MMCs, and titanium and its alloys. From the parametric optimization point of view, various advanced optimization techniques, like biogeography-based optimization, cuckoo search optimization, artificial bee colony optimization etc. are identified as the most popular methods, followed by grey relational analysis (GRA) and genetic algorithm (GA). In single objective optimization, among all the considered responses, each of them is separately optimized and different parametric combinations are derived for each of the responses which are quite difficult to maintain from the machining point of view. Rather, multi-objective optimization is more practical because in this approach, a unique parametric setting is obtained while simultaneously optimizing all the conflicting responses. Among the 14 research papers identified dealing with parametric optimization of ECM processes, ten papers considered only multi-objective optimization of the responses, while the remaining papers provided emphasis on both single and multi-objective optimization of the responses.

\subsection{EDM process}

Although, Joseph Preistly first observed the principles of the EDM process in 1770, two Soviet researchers, the Lazarenkos', succeeded in the development of a machining process in the 1940's that formed the foundation for the present EDM system. In this process, electrical energy is utilized to originate electrical spark between an electrode and a workpiece, and material removal principally takes place due to electro-discharge erosion. An intense heat with temperature between $8000^{\circ}-12000^{\circ} \mathrm{C}$ is generated by this electric spark, which when carefully controlled and localized, can only affect the workpiece surface. The metal removal mechanism is based on the application of a pulsating (on/off) electrical charge carrying high frequency current through the electrode to the workpiece, which causes controlled erosion of minute particles of metal from the workpiece. Instant vapourization and melting of the material are thus responsible for material removal. The tool and the work material are submerged 
in a dielectric medium (kerosene or deionized water which also acts as a coolant and washes out the eroded metal particles), and a gap is steadily maintained between the tool and the workpiece. In EDM process, both the tool and the workpiece material must be good conductor of electricity. Thus, any material that is electrically conductive (steel, titanium, superalloys, brass etc.) can easily be machined using this process (Ho and Newman, 2003). Its major advantages include limited heat affected zone (HAZ), surface hardening, no burr formation, generation of complex part geometries and faster machining operation. It has huge applications in die and mold making industries. Its various control parameters are open circuit voltage, spark gap, pulse-on time, pulse-off time, maximum (peak) current, polarity, dielectric medium etc.

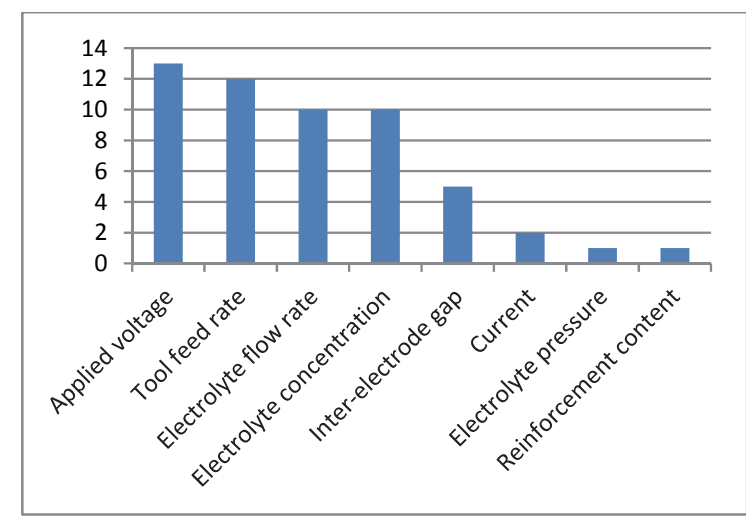

(a)

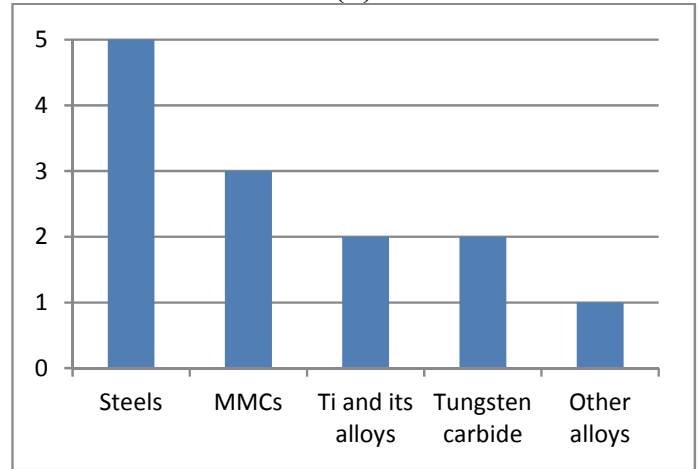

(c)

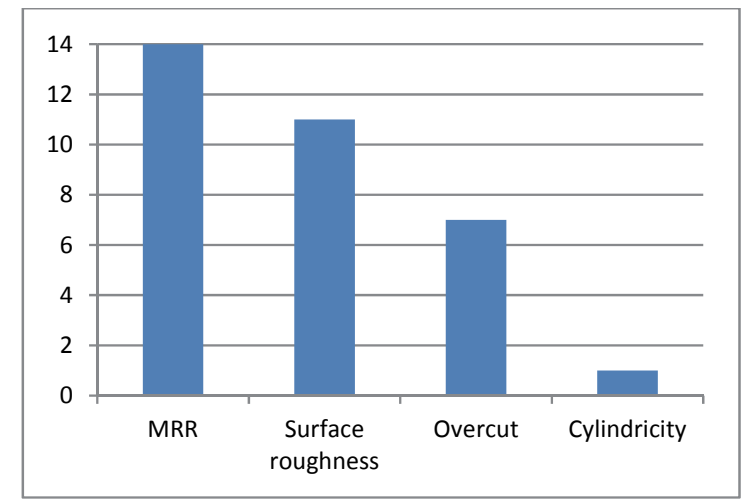

(b)

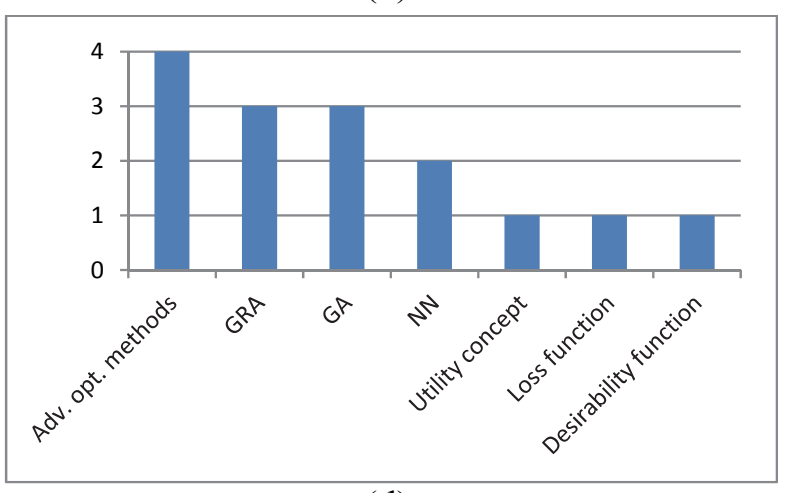

(d)

Fig. 1 Analysis on the parametric optimization of ECM processes

A list of the reviewed research papers on parametric optimization of EDM processes is provided in Table 2. On the other hand, the pertinent information regarding the process parameters and responses selected, work materials machined and optimization techniques adopted are provided in Fig. 2. It can be revealed from this figure that supply current, pulse-on time and pulse-off time are the three most predominant parameters for EDM process. They are subsequently followed by other parameters, like gap voltage, duty factor/duty cycle, applied voltage, tool rotational speed, pulse duration, tool electrode lift time, flushing pressure etc. according to their preference. Some least important process parameters, like feed rate, work time, capacitance, machining polarity, dielectric level, tool material, dielectric flow rate, aspect ratio of the tool, no load voltage, inter-electrode gap etc. are merged together into a single group (treated as others). These parameters are not so common in EDM processes, and their availability and settings mainly count on the type of EDM machine employed for material removal and part generation. Among the responses, MRR, surface roughness and electrode wear rate (EWR) have the maximum importance, followed by overcut, taper ratio, white layer thickness, surface crack density etc. Circularity, process energy, residual stress, process time, dielectric consumption etc. are identified as the least important responses. It is interestingly noted that different grades of steel (mainly AISI varieties) and alloys (Inconel 718, Invar, aluminum alloys and Rene 80) are the widely machined work 
materials using EDM process. Different MMCs, titanium and its alloys, and ceramics (aluminum oxide) are also machined by this process. For parametric optimization of EDM process, GRA is the most popular technique, followed by the other advanced optimization methods (like bio-geography based optimization, teaching learning-based optimization, particle swarm optimization etc.), principal component analysis (PCA), non-sorting genetic algorithm (NSGA-II), desirability function, neural networks (NN), simulated annealing (SA) etc. For this process, only a single paper considered single objective optimization, 31 papers attempted multi-objective optimization and the remaining four papers took into account both single and multi-objective optimization of the responses.

\subsection{WEDM process}

The principle of material removal in WEDM process is quite identical to that of EDM process. In this process, material is gradually worn out from the workpiece using a series of sparks generating between the workpiece and the wire isolated by a flow of dielectric fluid. This fluid is continuously supplied into the machining zone, enabling complex shapes being generated with high accuracy. The wire is made of thin copper, tungsten or brass having diameter $0.05-0.3 \mathrm{~mm}$. Because of its versatility, it is used in several areas, like aviation, medical, electronics and semiconductor applications, tool and die making industries, manufacturing of fixtures, gauges, cams, gears, strippers, punches, electrodes etc. As this process employs no force and does not form burrs, it can be effectively applied for machining of delicate parts (Ho et al., 2004). Its different process parameters include peak current, supply voltage, pulse-on time, pulse-off time, polarity, work material, size and speed of wire, feed rate, gain, rate of flushing, type of the dielectric medium etc.

Table 1

Parameters, responses, work materials and optimization techniques considered in ECM processes

\begin{tabular}{|c|c|c|c|c|c|c|}
\hline $\begin{array}{l}\text { Sl. } \\
\text { No. }\end{array}$ & Name of the authors & $\begin{array}{l}\text { Work material } \\
\text { machined }\end{array}$ & $\begin{array}{l}\text { Single/ } \\
\text { Multi- } \\
\text { objective }\end{array}$ & $\begin{array}{l}\text { Optimization tool(s) } \\
\text { adopted }\end{array}$ & Process parameters & Responses \\
\hline 1. & Abuzied et al. (2012) & - & Multiple & $\begin{array}{l}\text { Artificial neural } \\
\text { network }\end{array}$ & $\begin{array}{l}\text { Electrolyte flow rate, applied volt- } \\
\text { age, tool feed rate }\end{array}$ & $\begin{array}{l}\text { MRR, surface } \\
\text { roughness }\end{array}$ \\
\hline 2. & Dhobe et al. (2014) & Titanium & Both & Quality loss function & $\begin{array}{l}\text { Electrolyte concentration, electrolyte } \\
\text { flow rate, tool feed rate, inter-elec- } \\
\text { trode gap, applied voltage }\end{array}$ & $\begin{array}{l}\text { MRR, surface } \\
\text { roughness }\end{array}$ \\
\hline 3. & $\begin{array}{l}\text { Gopal and Chakrachar } \\
\text { (2012) }\end{array}$ & EN31 steel & Multiple & $\begin{array}{l}\text { Grey relational } \\
\text { analysis }\end{array}$ & $\begin{array}{l}\text { Electrolyte concentration, applied } \\
\text { voltage, tool feed rate }\end{array}$ & $\begin{array}{l}\text { MRR, overcut, } \\
\text { cylindricity }\end{array}$ \\
\hline 4. & Jegan et al. (2013) & $\begin{array}{l}\text { Metal matrix } \\
\text { composites }\end{array}$ & Multiple & $\begin{array}{l}\text { Weighted sum genetic } \\
\text { algorithm }\end{array}$ & $\begin{array}{l}\text { Current, applied voltage, tool feed } \\
\text { rate, electrolyte concentration }\end{array}$ & $\begin{array}{l}\text { MRR, surface } \\
\text { roughness }\end{array}$ \\
\hline 5. & $\begin{array}{l}\text { Kalaimathi et al. } \\
\text { (2014) }\end{array}$ & Monel 400 alloy & Multiple & Desirability function & $\begin{array}{l}\text { Inter-electrode gap, applied voltage, } \\
\text { electrolyte concentration }\end{array}$ & $\begin{array}{l}\text { MRR, surface } \\
\text { roughness }\end{array}$ \\
\hline 6. & $\begin{array}{l}\text { Manikandan et al. } \\
\qquad(2015)\end{array}$ & $\begin{array}{l}\text { Ti-6Al-4V titanium } \\
\text { alloy }\end{array}$ & Both & $\begin{array}{l}\text { Grey relational } \\
\text { analysis }\end{array}$ & $\begin{array}{l}\text { Tool feed rate, electrolyte } \\
\text { concentration, electrolyte flow rate }\end{array}$ & MRR, overcut \\
\hline 7. & $\begin{array}{l}\text { Mukherjee and } \\
\text { Chakraborty (2013) }\end{array}$ & EN8 steel & Both & $\begin{array}{l}\text { Biogeography-based } \\
\text { optimization }\end{array}$ & $\begin{array}{l}\text { Electrolyte concentration, applied } \\
\text { voltage, electrolyte flow rate, } \\
\text { inter-electrode gap }\end{array}$ & MRR, overcut \\
\hline 8. & $\begin{array}{l}\text { Rao and Pad- } \\
\text { manabham (2015) }\end{array}$ & $\begin{array}{l}\text { Aluminium matrix } \\
\text { and boron carbide } \\
\text { metal matrix com- } \\
\text { posite }\end{array}$ & Both & Utility concept & $\begin{array}{l}\text { Applied voltage, electrolyte flow } \\
\text { rate, tool feed rate, reinforcement } \\
\text { content }\end{array}$ & $\begin{array}{l}\text { MRR, } \\
\text { surface roughness, } \\
\text { radial overcut }\end{array}$ \\
\hline 9. & $\begin{array}{l}\text { Sathiyamoorthy et al. } \\
\qquad(2015)\end{array}$ & $\begin{array}{l}\text { High carbon high } \\
\text { chromium die tool } \\
\text { steel }\end{array}$ & Multiple & Genetic algorithm & $\begin{array}{l}\text { Applied voltage, inter-electrode gap, } \\
\text { tool feed rate, electrolyte discharge } \\
\text { rate }\end{array}$ & $\begin{array}{l}\text { MRR, surface } \\
\text { roughness }\end{array}$ \\
\hline 10. & $\begin{array}{l}\text { Sathiyamoorthy and } \\
\text { Sekar (2016) }\end{array}$ & $\begin{array}{l}\text { AISI } 202 \text { stainless } \\
\text { steel }\end{array}$ & Multiple & Genetic algorithm & $\begin{array}{l}\text { Applied voltage, tool feed rate, elec- } \\
\text { trolyte discharge rate }\end{array}$ & $\begin{array}{l}\text { MRR, surface } \\
\text { roughness }\end{array}$ \\
\hline 11. & $\begin{array}{l}\text { Sohrabpoor et al. } \\
\qquad(2016)\end{array}$ & $\begin{array}{l}\text { Cemented tungsten } \\
\text { carbide }\end{array}$ & Multiple & $\begin{array}{l}\text { Cuckoo optimization } \\
\text { algorithm }\end{array}$ & $\begin{array}{l}\text { Electrolyte concentration, applied } \\
\text { voltage, electrolyte flow rate, tool } \\
\text { feed rate }\end{array}$ & $\begin{array}{lr}\text { MRR, } & \text { surface } \\
\text { roughness, } & \text { radial } \\
\text { overcut }\end{array}$ \\
\hline 12. & $\begin{array}{l}\text { Solaiyappan et al. } \\
\qquad(2014)\end{array}$ & $\begin{array}{l}\text { Silicon carbide } \\
\text { composite }\end{array}$ & Multiple & $\begin{array}{l}\text { Hybrid fuzzy-artificial } \\
\text { bee colony algorithm }\end{array}$ & $\begin{array}{l}\text { Applied voltage, electrolyte flow } \\
\text { rate, current, inter-electrode gap, tool } \\
\text { feed rate, electrolyte concentration }\end{array}$ & $\begin{array}{l}\text { MRR, surface } \\
\text { roughness, overcut }\end{array}$ \\
\hline 13. & Tang and Yang (2013) & $\begin{array}{l}\text { Special stainless } \\
\text { steel } \\
\text { 00Cr12Ni9Mo4Cu2 }\end{array}$ & Multiple & $\begin{array}{l}\text { Grey relational analy- } \\
\text { sis }\end{array}$ & $\begin{array}{l}\text { Applied voltage, electrolyte pressure, } \\
\text { electrolyte concentration, tool feed } \\
\text { rate }\end{array}$ & $\begin{array}{l}\text { MRR, side gap, } \\
\text { surface roughness }\end{array}$ \\
\hline 14. & $\begin{array}{l}\text { Teimouri and Shor- } \\
\text { abpoor (2013) }\end{array}$ & $\begin{array}{l}\text { Cemented tungsten } \\
\text { carbide }\end{array}$ & Multiple & $\begin{array}{l}\text { Adaptive neuro-fuzzy } \\
\text { inference system, } \\
\text { cuckoo optimization } \\
\text { algorithm }\end{array}$ & $\begin{array}{l}\text { Electrolytic concentration, applied } \\
\text { voltage, electrolyte flow rate, tool } \\
\text { feed rate }\end{array}$ & $\begin{array}{l}\text { MRR, surface } \\
\text { roughness }\end{array}$ \\
\hline
\end{tabular}




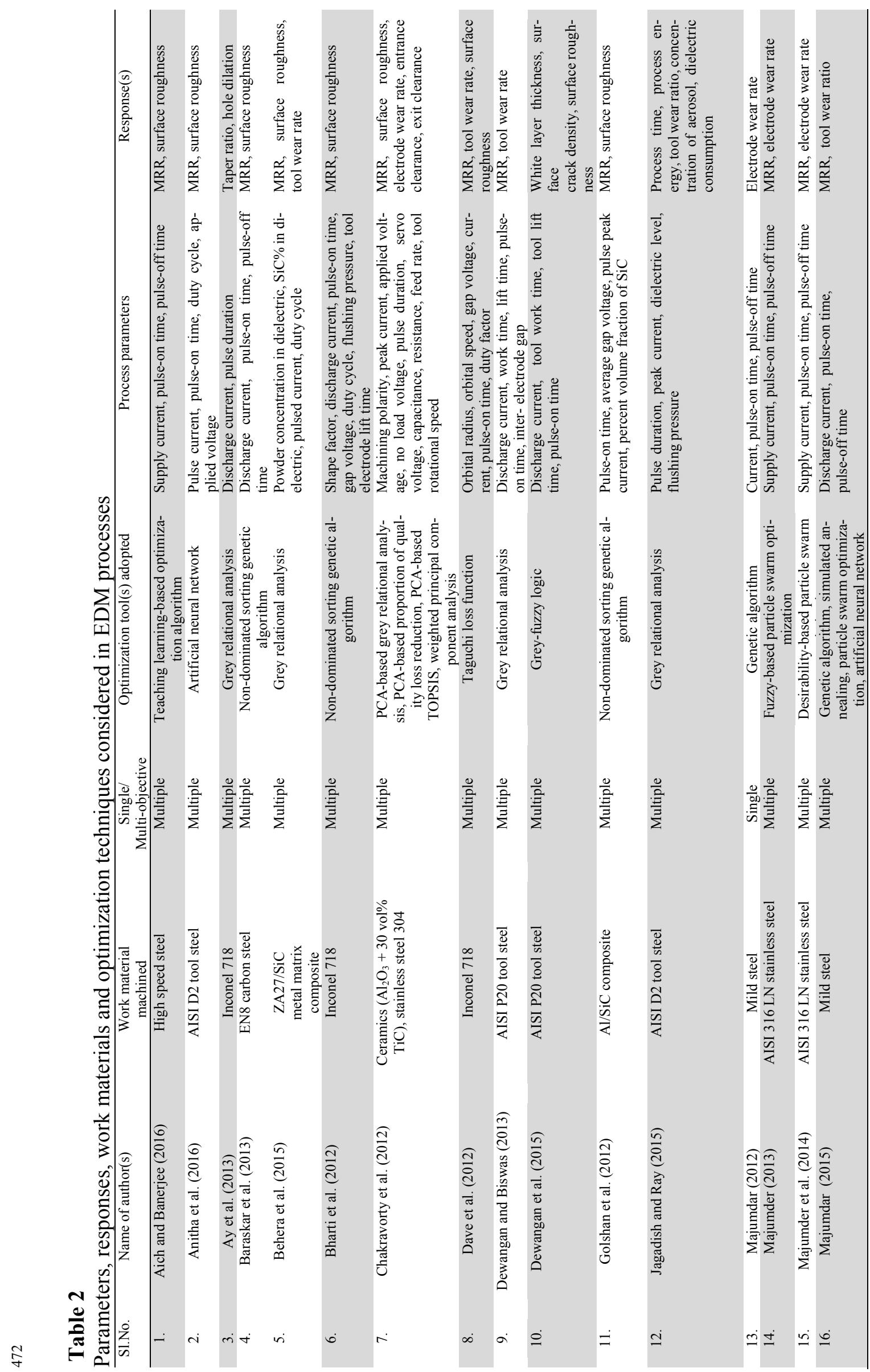




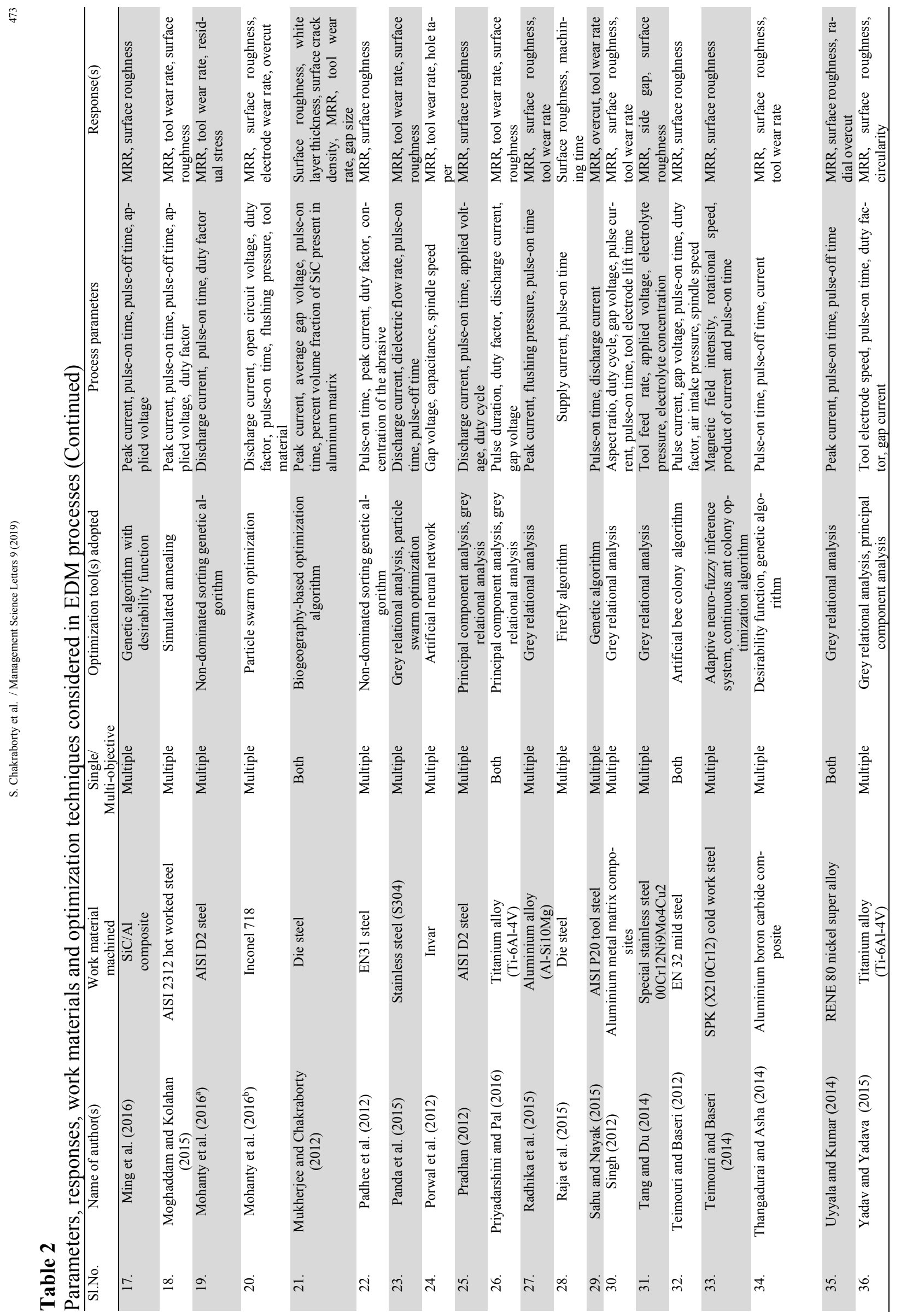




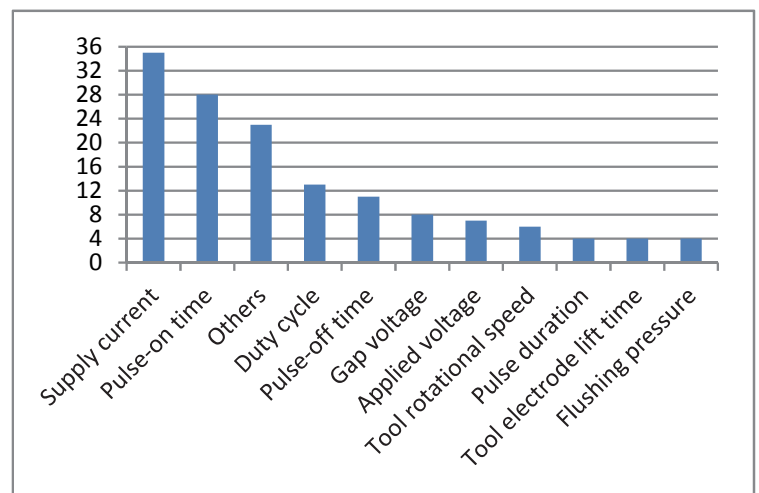

(a)

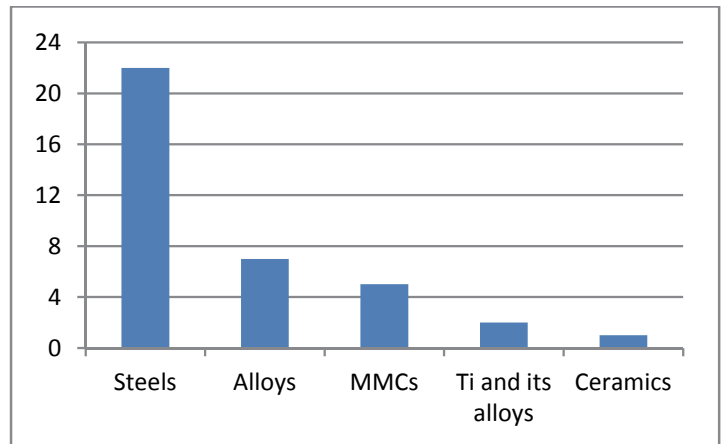

(c)

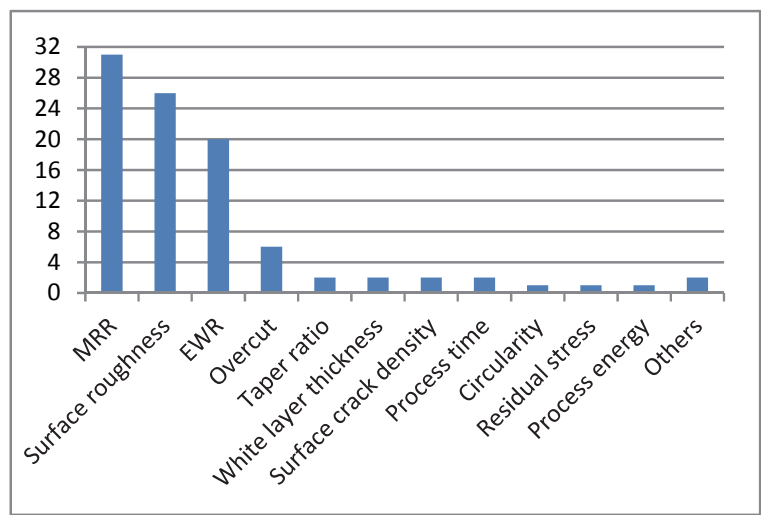

(b)

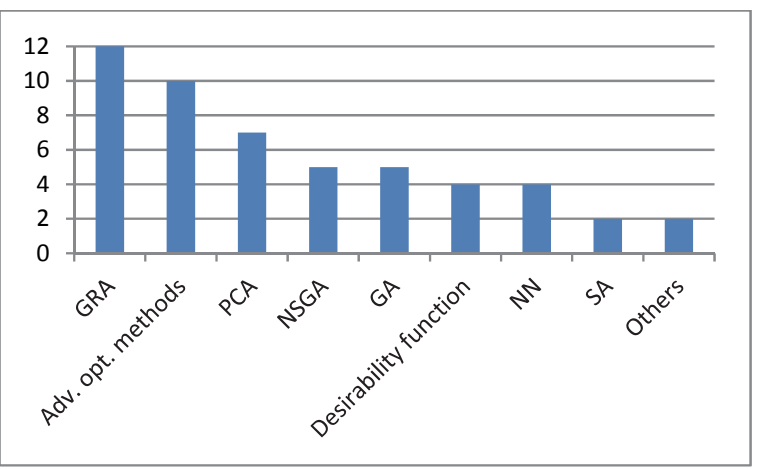

(d)

Fig. 2 Analysis on the parametric optimization of EDM processes

In Table 3, the parameters and responses considered, work materials machined and optimization techniques adopted for parametric optimization of WEDM processes are listed based on the reviewed research papers. Figure 3 presents the related detailed analyses. It can be noticed that for WEDM process, wire feed rate, pulse-off time and pulse-on time are the most frequently set process parameters, followed by wire tension, current, gap voltage, flushing pressure, pulse duration, servo feed and workpiece thickness. There are also some insignificant process parameters, like spark gap, capacitance, duty factor, pulse frequency, taper angle, power, dielectric flow rate, rotational speed, corner servo etc. as set by different researchers depending on their availability and settings in the WEDM set-ups. Among the responses, surface roughness is provided with the maximum priority, followed by MRR, cutting rate, overcut, wire wear rate (WWR), kerf width and angular error. Spark gap, machining time and white layer thickness are also the other responses which are less frequently considered by the researchers. In WEDM processes, different grades of steel and alloys (specially Inconel) are the most commonly machined work materials, followed by titanium and its alloys, MMCs, aluminum and its alloys, and tungsten carbide. For parametric optimization of WEDM processes, different advanced optimization methods along with NSGA are the most popular approaches among the researchers, followed by GA, GRA, utility concept, desirability function, SA, NN and PCA. Out of 28 research papers surveyed, 17 of them dealt with multi-objective optimization, and the remaining papers considered both single and multi-objective optimization of WEDM responses.

\subsection{LBM process}

In LBM process, a laser beam with high energy density is made to focus on the workpiece surface. The work volume is heated by the absorbed thermal energy and transformed into a molten, vaporized or modified into another chemical state, and is subsequently removed from the machining zone using a high pressure assist gas jet (Meijer, 2004). Thus, melting, vaporization and chemical degradation (chemical bonds are disintegrated causing the material to dissipate) are the three stages of the material removal mechanism in LBM process (Dubey \& Yadava, 2008). Ruby (chromium alumina alloy), Nd-glass laser, 
Nd-YAG laser etc. are the examples of solid state laser, whereas, Helium-Neon, Argon, $\mathrm{CO}_{2}$ etc. are the gas lasers. The LBM process has several advantages, such as no built-up edge formation, low operating cost, no tool wear, rapid machining ability, capability of generating very tiny holes at difficult entrance angles etc. It is most suitably deployed for welding of non-conductive and refractory materials, and also for drilling, cutting, grooving, scribing, trimming and patterning operations. Its main process parameters include pulse shape, pulse frequency, wave length, duration, laser energy, assist gas type and pressure, focal length and position etc. A list of the reviewed research papers published during 2012-16 on parametric optimization of LBM processes is provided in Table 4, and Fig. 4 exhibits the parameters and responses selected, work materials machined and optimization techniques deployed in those processes. Pulse frequency, assist gas pressure, cutting speed and pulse width are identified as the most significant process parameters, followed by laser power, lamp current and focus position. There are also some other insignificant parameters, e.g. Y feed rate, workpiece thickness, arc radius etc., which are less frequently chosen by the past researchers. Surface roughness, HAZ, hole taper and kerf taper are the maximally preferred responses for their optimization; although, other responses, like top kerf width, upper deviation, channel width, burr height, depth deviation, MRR, lower deviation are also given due importance. In these processes, some unimportant responses, like burr width, depth of separation line, drag line separation and channel width are also noticed to exist. Among the work materials, aluminium and its different alloys are primarily machined using LBM process, followed by various ceramics (alumina and zirconia) and thermoplastic polymers. Other materials, like different grades of steel, Inconel 718, and titanium and its alloys are also machined using LBM process, but their occurrences are observed to be quite less as compared to other work materials. For parametric optimization of LBM processes, GRA is identified as the most effective method, followed by the application of different advanced optimization techniques. Other optimization methods, like GA, PCA, NSGA etc. are also occasionally adopted by the past researchers for the said purpose. Among 18 research papers reviewed, 16 papers considered multi-objective optimization, while one paper dealt with single objective optimization of the responses. There is only a single paper where both single and multi-objective optimization of the responses were considered.

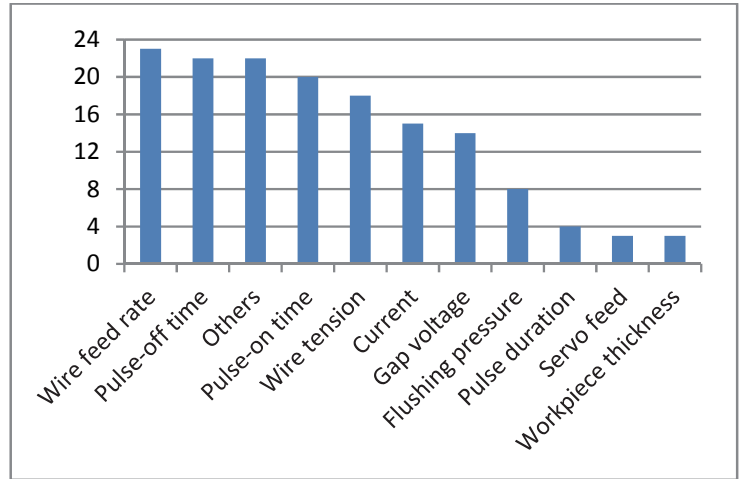

(a)

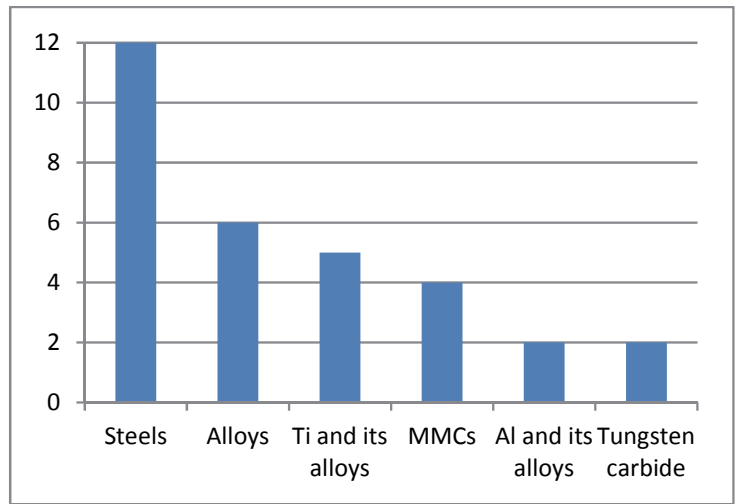

(c)

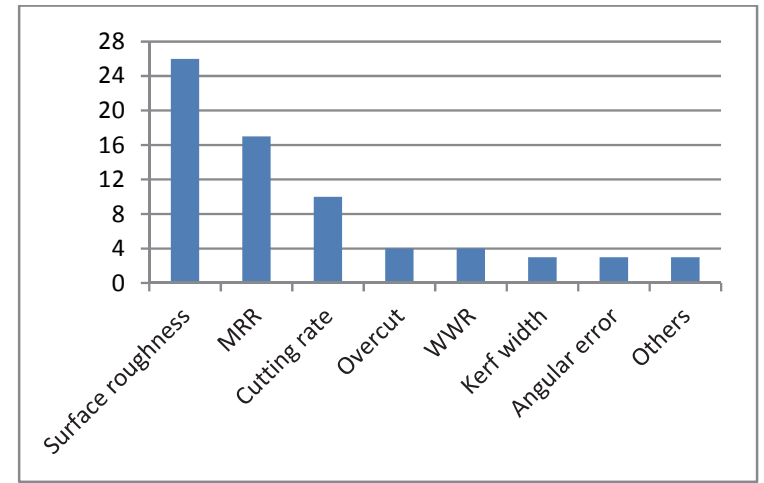

(b)

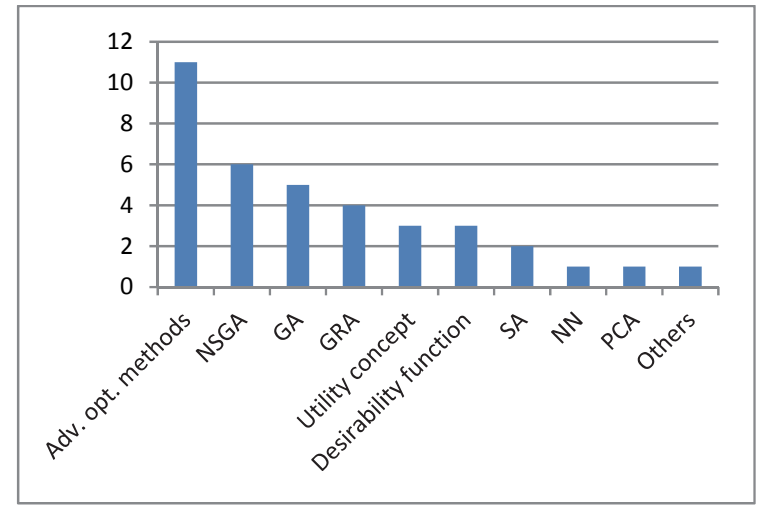

(d)

Fig. 3 Analysis on the parametric optimization of WEDM processes 


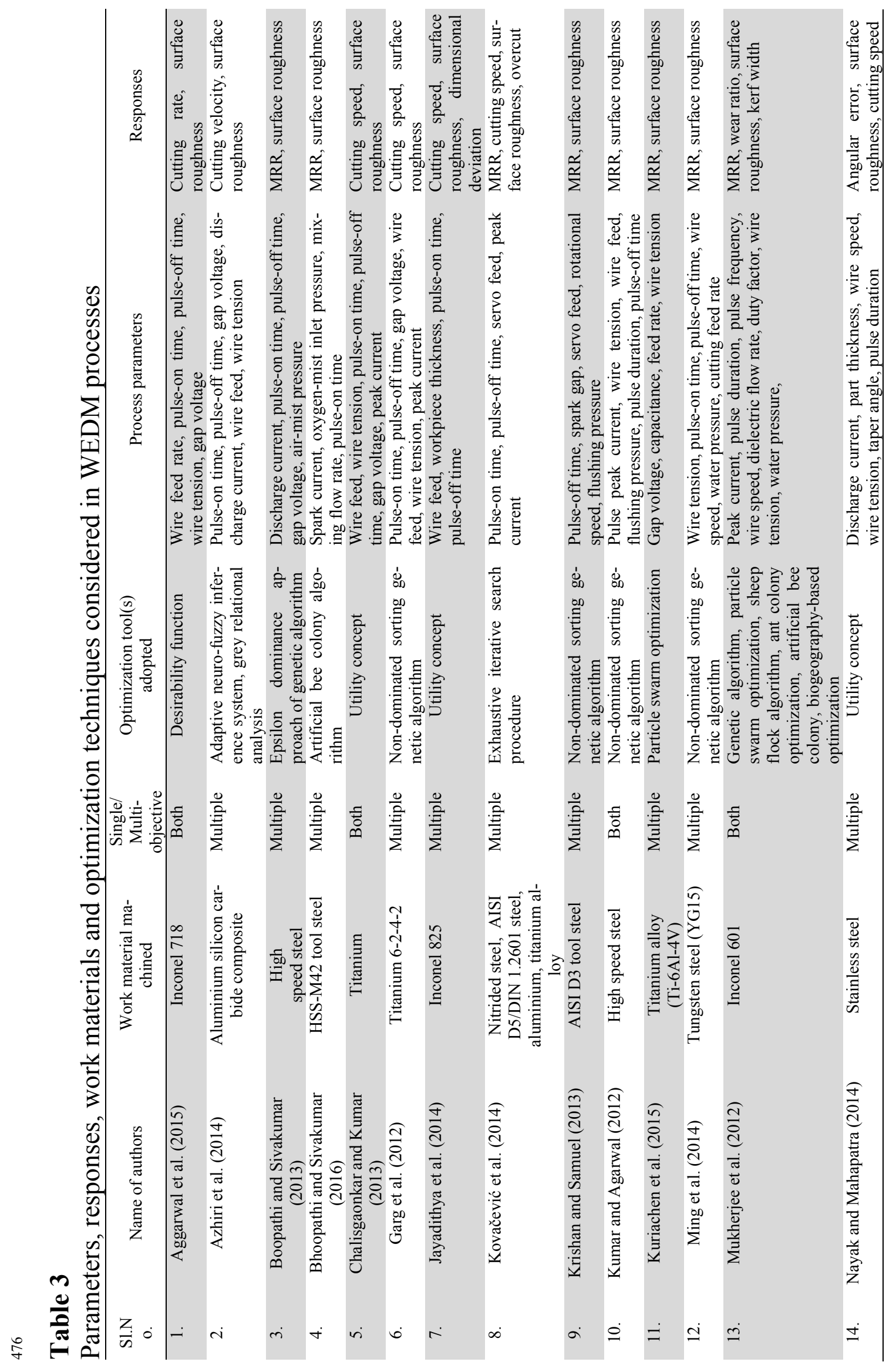




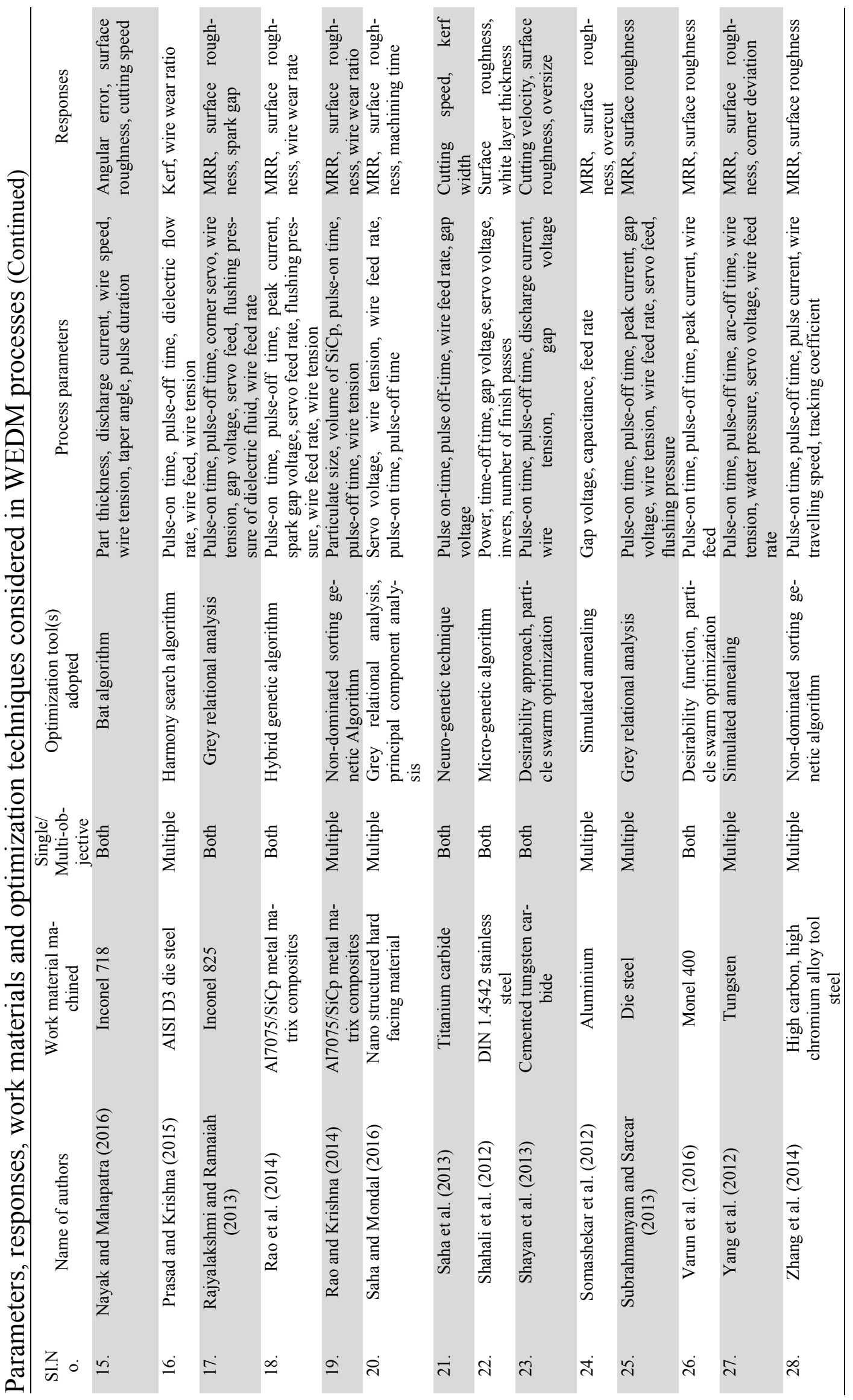




\subsection{USM process}

In USM process, a tool having the appropriate shape geometry oscillates over the workpiece at an ultrasonic frequency of 19 25 kHz and amplitude of 15-50 $\mu \mathrm{m}$. Between the tool and the workpiece, the machining zone is deluged with abrasive particles $\left(\mathrm{Al}_{2} \mathrm{O}_{3}, \mathrm{SiC}, \mathrm{B} 4 \mathrm{C}\right.$, diamond etc.) mixed with water to form of a water-based slurry. When the tool oscillates over the workpiece, the abrasive particles make indentations to remove material from the workpiece. Crack initiation, propagation and brittle fracture are the three phases causing removal of material in USM process. It can be effectively employed for generating square, round, irregular shaped holes and surface impressions on hard and brittle materials, like glass, ceramics, stones, carbides, silicon nitride, nickel/titanium alloys etc. (Thoe et al., 1998). Amplitude and frequency of vibration, feed force and pressure, abrasive size and material, contact area of the tool, volume concentration of abrasive in slurry etc. are the different parameters influencing the machining performance of USM process.

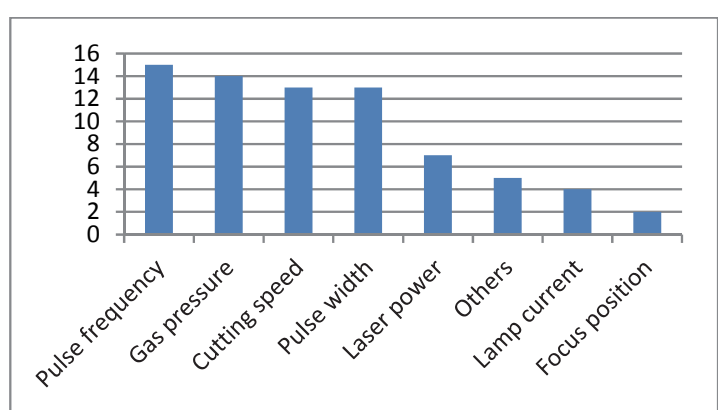

(a)

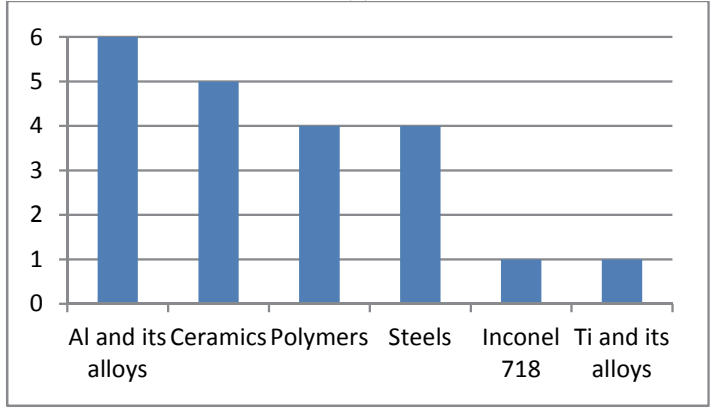

(c)

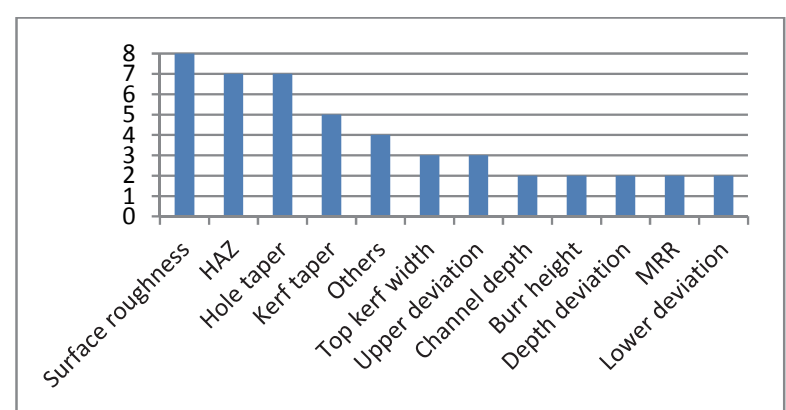

(b)

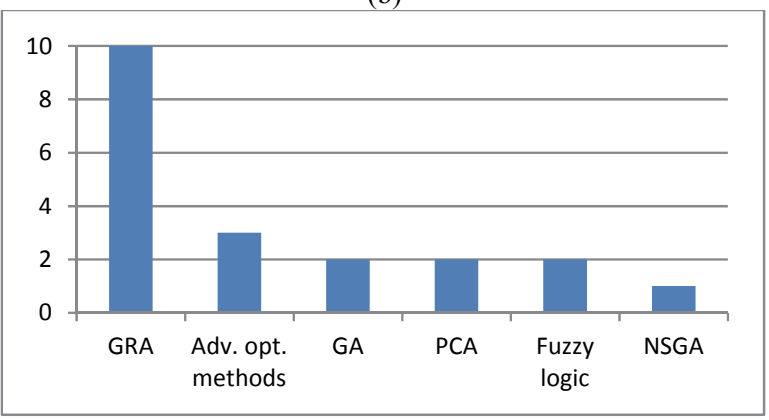

(d)

Fig. 4 Analysis on the parametric optimization of LBM processes

Table 5 presents a list of the reviewed research papers published during 2012-16 on parametric optimization of USM processes, and Fig. 5 provides an idea on the process parameters and responses, work materials and optimization techniques selected in those considered processes. It can be easily revealed that grit size and power rating are the two important control parameters mostly preferred by the past researchers, followed by the type of tool material, slurry concentration and tool feed rate. Tool profile, and type and thickness of the work material are some of the least preferred machining parameters for USM process. In this process, maximum importance is allocated to the optimization of surface roughness and MRR, followed by tool wear rate (TWR) and overcut. Titanium is identified as the most widely machined work material in USM process. It is also employed for machining of different ceramics (mainly zirconia) and MMCs. Among the optimization tools, GRA, utility concept and different advanced optimization techniques are mainly utilized for parametric optimization of USM processes. Other tools, such as GA, NN and Taguchi loss function are also applied for the same purpose. There are applications of weighted signal-to-noise ratio and multi-response signal-to-noise ratio for simultaneous optimization of USM responses. From Table 5, it can be noticed that four research papers dealt with multi-objective optimization, while three papers considered both single as well as multi-objective optimization of the responses for USM process. 


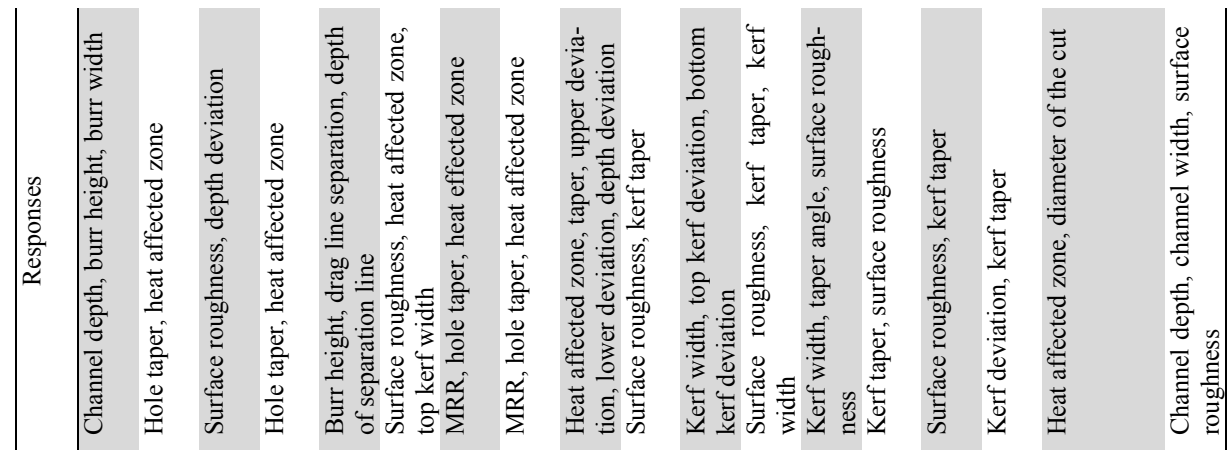

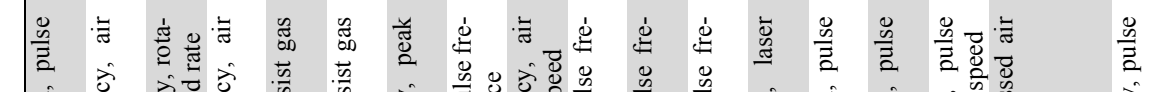

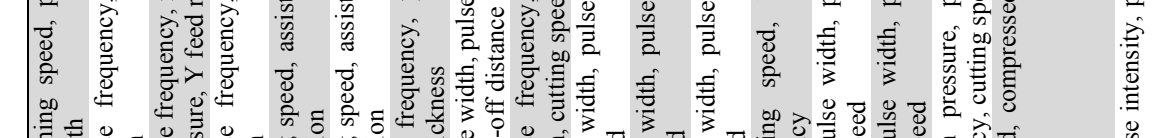

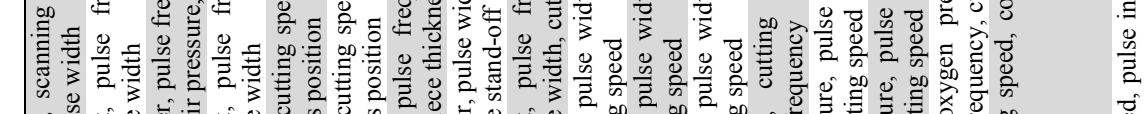

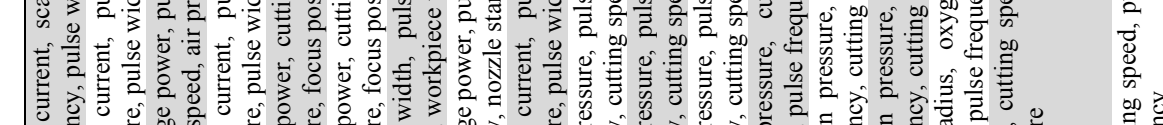

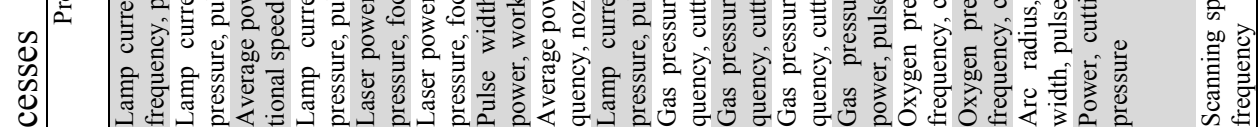

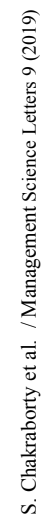

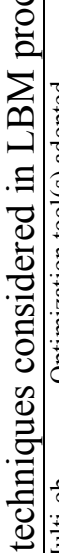

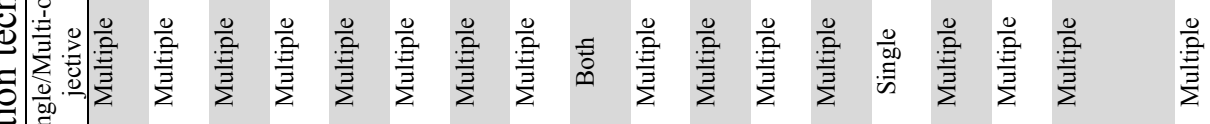

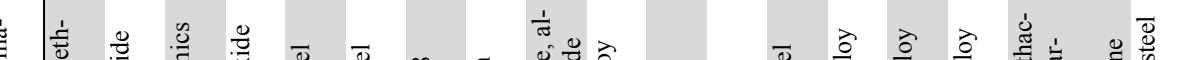

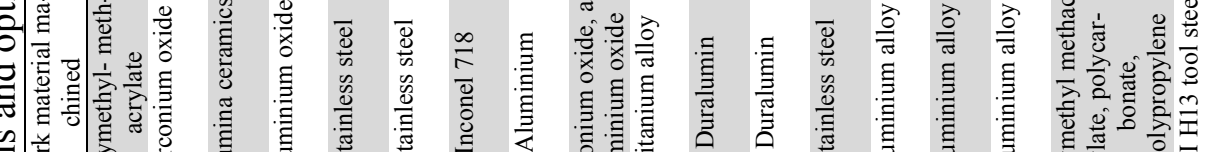

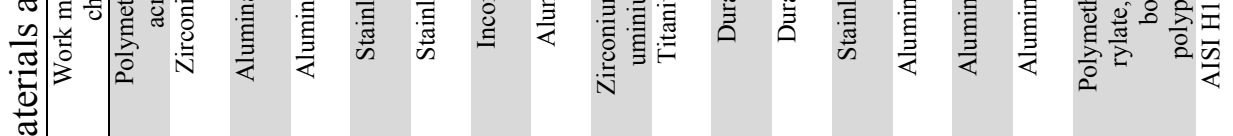

ำ

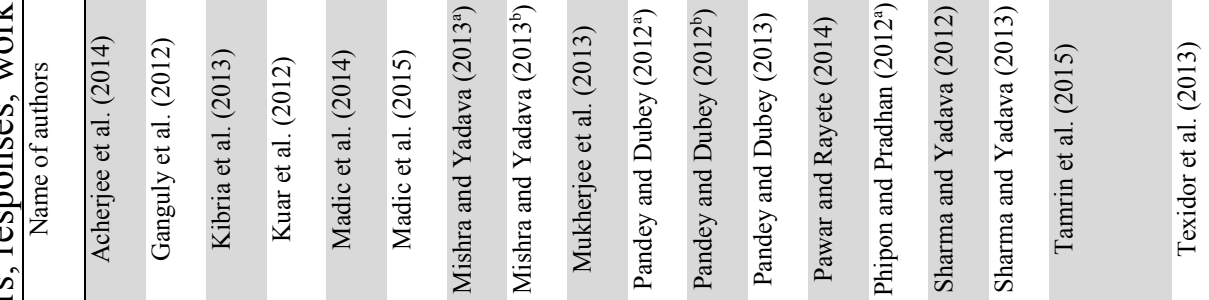

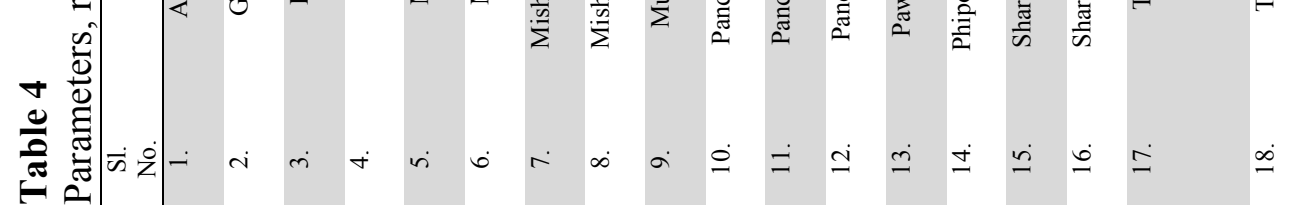




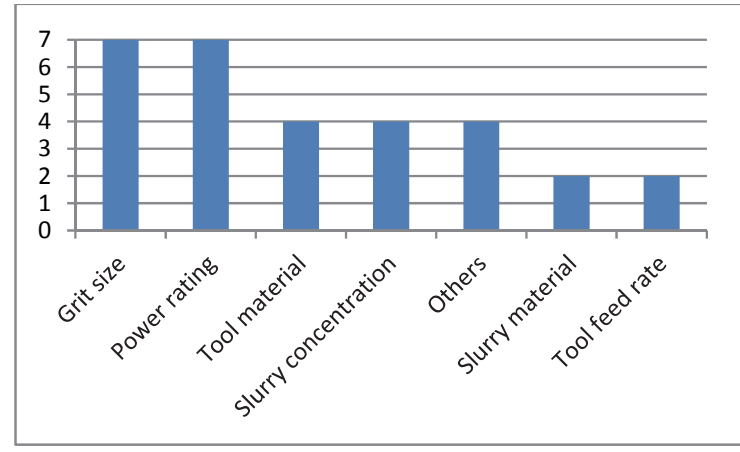

(a)

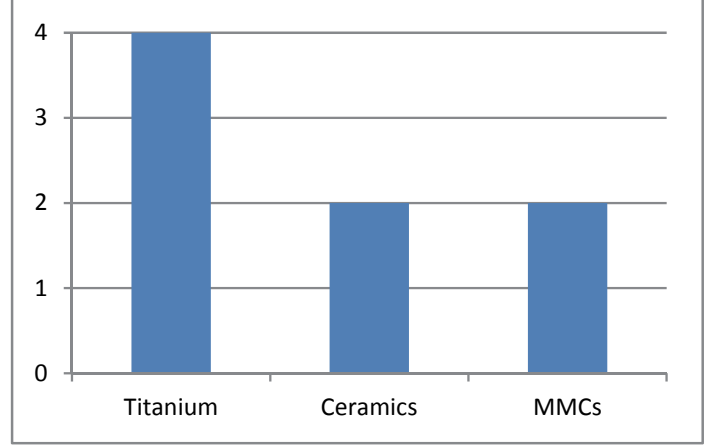

(c)

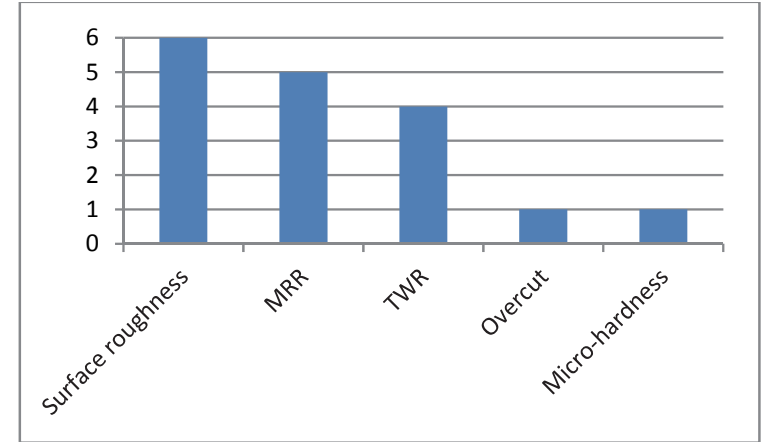

(b)

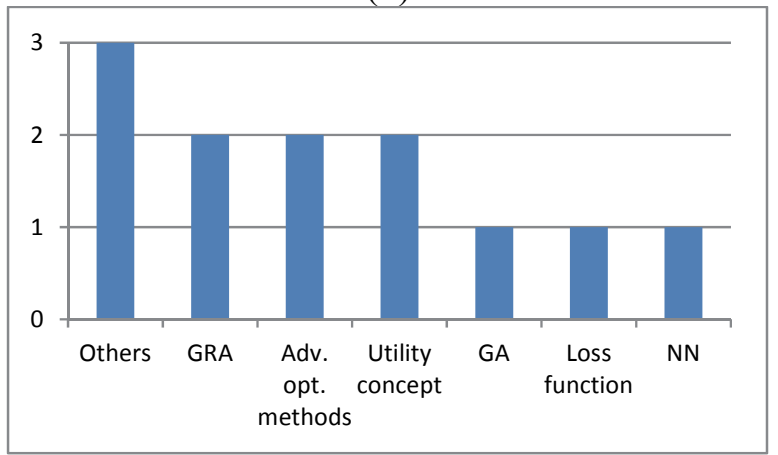

(d)

Fig. 5 Analysis on the parametric optimization of USM processes

\subsection{HM processes}

Technological improvement of NTM processes can be efficiently attained when different machining actions or phases are combined together for material removal. This combination of individual processes leads to the subsequent development of a HM process where the combined advantages of the constituent processes can be achieved while avoiding or reducing some of their adverse effects when they are applied individually (El-Hofy, 2005). The performance characteristics of a HM process are expected to be better than those of the single-phase processes with respect to productivity, accuracy and surface quality (Sundaram, 2014). In AJWM process, the mechanical energy of water and abrasive particles is utilized to remove material from the workpiece. In this process, abrasive particles, like sand $\left(\mathrm{SiO}_{2}\right)$, glass beads etc. are mixed with the water jet to enhance its machining capability by many folds (Janković et al., 2012). The ECDM is also a hybrid NTM process combining the features of ECM and EDM processes. It consists of a tool (cathode), an auxiliary electrode (anode) and a workpiece, which are isolated by a gap filled with electrolyte, and a pulsed DC is applied between them. This causes generation of electrical discharges between the tool and electrolyte where the workpiece is placed, thus attaining both electrochemical dissolution and electro discharge erosion of the workpiece (Mediliyegedara et al., 2005). The TW-ECSM process combines the material removal mechanisms of ECM and WEDM processes (Malik and Manna, 2017). It can be efficaciously employed for machining of hard-to-machine non-conductive materials that cannot be machined by the other NTM processes, like EDM, ECM, WEDM etc. Electrical discharge diamond grinding (EDDG) is a hybridized NTM process, consisting of EDM with rotary disc electrode and grinding using diamond abrasives (Yadav et al., 2012). During EDDG, the electrically nonconducting reinforcements that hinder the generation of sparks can be removed by the abrasion action of diamond abrasives. On the other hand, the wheel loading and clogging problems can be avoided due to electrical sparks, and dressing of diamond wheel can also take place. In magnetic abrasive finishing (MAF) process, the workpiece is kept between the two poles of a magnet, and the machining gap between the workpiece and the magnet is flooded with magnetic abrasive particles. A magnetic abrasive flexible brush is thus formed, which acts as a multipoint cutting tool, due to the effect of magnetic field in the 
machining gap (Kumar et al., 2013). The ECG combines electrochemical dissolution and mechanical grinding processes (Goswami et al., 2009). The workpiece is connected to the positive electrode and an electrically conductive grinding wheel is made as the negative electrode. As the electric current flows between the workpiece and wheel through the electrolyte, electrochemical dissolution takes places causing material to be removed from the workpiece. Mechanical abrasion is also responsible for material removal to some extent.

\section{Table 5}

Parameters, responses, work materials and optimization techniques considered in USM processes

\begin{tabular}{|c|c|c|c|c|c|c|}
\hline Sl.No. & $\begin{array}{l}\text { Name of } \\
\text { author(s) }\end{array}$ & $\begin{array}{c}\text { Work } \\
\text { material } \\
\text { machined }\end{array}$ & $\begin{array}{l}\text { Single/ } \\
\text { Multi- } \\
\text { objective }\end{array}$ & $\begin{array}{l}\text { Optimization tool(s) } \\
\text { adopted }\end{array}$ & Process parameters & Responses \\
\hline 1. & $\begin{array}{l}\text { Chakravorty et } \\
\text { al. (2013) }\end{array}$ & $\begin{array}{l}\text { Cobalt, } \\
\text { tungsten } \\
\text { carbide }\end{array}$ & Multiple & $\begin{array}{l}\text { Weighted signal-to-noise } \\
\text { ratio, utility theory, grey } \\
\text { relational analysis, multi- } \\
\text { response } \\
\text { signal-to-noise ratio }\end{array}$ & $\begin{array}{l}\text { Tool material, abrasive slurry } \\
\text { material, slurry concentration, } \\
\text { grit size of slurry material, } \\
\text { power rating }\end{array}$ & $\begin{array}{l}\text { MRR, tool wear } \\
\text { rate, surface } \\
\text { roughness }\end{array}$ \\
\hline 2. & $\begin{array}{l}\text { Cheema et al. } \\
\text { (2013) }\end{array}$ & $\begin{array}{l}\text { Titanium } \\
\text { (ASTM Gr 2), } \\
\text { Titanium } \\
\text { (ASTM Gr 5) }\end{array}$ & Both & Utility concept & $\begin{array}{l}\text { Workpiece material, abrasive } \\
\text { grit size, abrasive slurry concen- } \\
\text { tration, power rating, tool mate- } \\
\text { rial }\end{array}$ & $\begin{array}{l}\text { Surface } \\
\text { roughness, tool } \\
\text { wear ratio, hole } \\
\text { oversize }\end{array}$ \\
\hline 3. & Das et al. (2013) & Zirconia & Multiple & Genetic algorithm & $\begin{array}{l}\text { Abrasive grit size, abrasive } \\
\text { slurry concentration, power } \\
\text { rating, tool feed rate }\end{array}$ & $\begin{array}{l}\text { MRR, surface } \\
\text { roughness }\end{array}$ \\
\hline 4. & $\begin{array}{l}\text { Goswami and } \\
\text { Chakraborty } \\
(2015)\end{array}$ & Zirconia & Both & $\begin{array}{l}\text { Gravitational search algo- } \\
\text { rithm, fireworks algorithm }\end{array}$ & $\begin{array}{l}\text { Grit size, slurry concentration, } \\
\text { power rating, tool feed rate }\end{array}$ & $\begin{array}{l}\text { MRR, surface } \\
\text { roughness }\end{array}$ \\
\hline 5. & $\begin{array}{l}\text { Kataria et al. } \\
\qquad(2016)\end{array}$ & $\begin{array}{l}\text { WC-Co } \\
\text { composite }\end{array}$ & Multiple & Grey relational analysis & $\begin{array}{l}\text { Cobalt content, } \\
\text { workpiece thickness, tool } \\
\text { profile, grit size, } \\
\text { power rating }\end{array}$ & $\begin{array}{l}\text { MRR, tool wear } \\
\text { rate }\end{array}$ \\
\hline 6. & Kumar (2014) & $\begin{array}{l}\text { Titanium } \\
\text { (ASTM Gr 1) }\end{array}$ & Both & Taguchi loss function & $\begin{array}{l}\text { Tool material, abrasive type, } \\
\text { grit size, power rating }\end{array}$ & $\begin{array}{l}\text { Surface } \\
\text { roughness, } \\
\text { micro-hardness }\end{array}$ \\
\hline 7. & $\begin{array}{l}\text { Teimouri et al. } \\
\text { (2015) }\end{array}$ & $\begin{array}{l}\text { Titanium } \\
\text { (ASTM Gr 1) }\end{array}$ & Multiple & $\begin{array}{l}\text { Adaptive neuro-fuzzy in- } \\
\text { ference system, imperialist } \\
\text { competitive algorithm }\end{array}$ & $\begin{array}{l}\text { Tool material, grit size, power } \\
\text { rating }\end{array}$ & $\begin{array}{l}\text { MRR, tool wear } \\
\text { rate, surface } \\
\text { roughness }\end{array}$ \\
\hline
\end{tabular}

In Table 6, a list of research papers published during 2012-16 on parametric optimization of HM processes (i.e. AJWM, ECDM, TW-ECSM, EDDG, MAF and ECG) is provided. The responses set in these six HM processes, work materials machined and optimization techniques employed for deriving the best parametric mix are shown in Fig. 6. As the control parameters in the considered HM processes are widely varying and entirely depend on the type of the machining set-up employed, it is not at all a wise decision to make an exhaustive list of those parameters. It can be perceived from Fig. 6 that among the responses, MRR and surface roughness are allotted with the maximum importance, followed by kerf width, HAZ, overcut, TWR, current density and depth of cut. In these processes, glass, MMCs, different grades of steel, and aluminium and its alloys are mostly machined for generation of different shape features for industrial use, followed by ceramics, brass, Inconel, tungsten carbide and silicon. With respect to the techniques adopted for parametric optimization of HM processes, GRA and advanced optimization methods become quite popular among the researchers. Other techniques, like NSGA. GA, NN, loss function, PCA, utility concept and desirability function are also applied for the same purpose. Among 30 papers surveyed on HM processes, 18 of them considered multi-objective optimization, while only four dealt with both single as well as multi-objective optimization of the responses. There are also eight research papers where the authors optimized only a single response.

\section{Discussions}

When all the reviewed papers are classified based on their year of publication, as depicted in Fig. 7, it can be clearly revealed that the earlier researchers maximally considered EDM process for its parametric optimization, followed by HM and WEDM processes. It is also quite interesting to notice that in this direction, maximum research works were mainly carried out in 2012 and 2014 for almost all the considered NTM processes. When all the responses, as considered by the past researchers for deriving their 
optimal values, are analyzed in Fig. 8, it can be observed that surface roughness has the top priority, followed by MRR. Other responses, like TWR, overcut, cutting rate, HAZ, taper, kerf width etc. have also moderate importance. There are several less significant responses, like cylindricity, white layer thickness, surface crack density, channel depth, burr height, depth deviation, lower deviation, current density etc. which are occasionally considered by the past researchers in order to satisfy varying end product requirements. It is a well known fact that NTM processes are mainly employed for generation of complex shape geometries on varying hard-to-machine materials which cannot be machined by the conventional material removal methods. From the reviewed papers, it can be clearly visualized that these processes were mainly utilized for machining of different grades of steel, followed by MMCs and various metal alloys to meet their high demands for diverse industrial applications. A list of different work materials machined by the considered NTM processes is graphically presented in Fig. 9. The application of various tools and techniques for parametric optimization of the considered NTM processes is exhibited in Fig. 10. It is quite interesting to observe that among all these applied methods, GRA supersedes the others due to its mathematical simplicity, comprehensiveness and capability for performing multi-objective optimization of the responses quite easily. But when GA, NSGA and SA are coupled together with the other advanced optimization methods, they become the most popular techniques due to their ability to solve both single and multi-objective optimization problems. These techniques are also capable of finding out the global optimal solutions for parametric optimization problems. Among the employed advanced optimization methods, particle swarm optimization algorithm is mostly preferred by the researchers, followed by artificial bee colony optimization and cuckoo optimization techniques, as shown in Fig. 11. Biogeography-based optimization, teaching learning-based optimization, ant colony optimization, firefly algorithm, bat algorithm, sheep flock algorithm, harmony search algorithm, gravitational search algorithm and fireworks algorithm are the other techniques applied for parametric optimization of the considered NTM processes according to their preference. It is observed that amongst 133 research papers surveyed, in only 10 papers $(7.52 \%)$, a single response was optimized; in 96 papers $(72.18 \%)$, multiple responses were optimized simultaneously; and 27 papers $(20.30 \%)$ dealt with both single as well as multi-objective optimization of the responses.

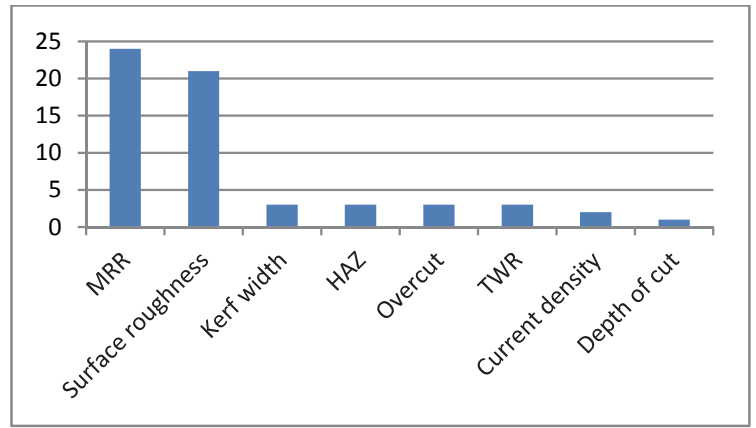

(a)

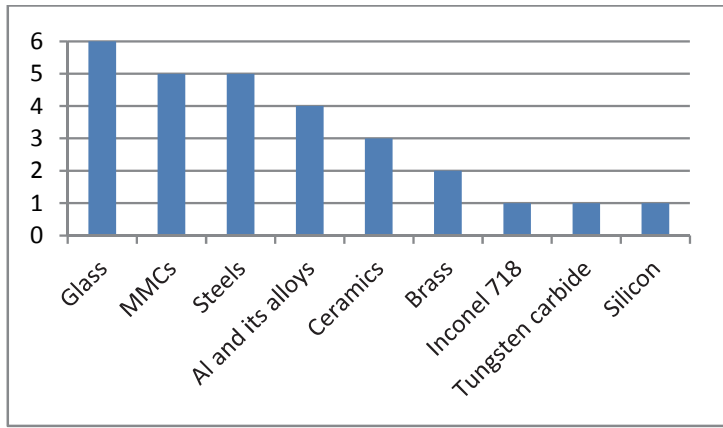

(b)

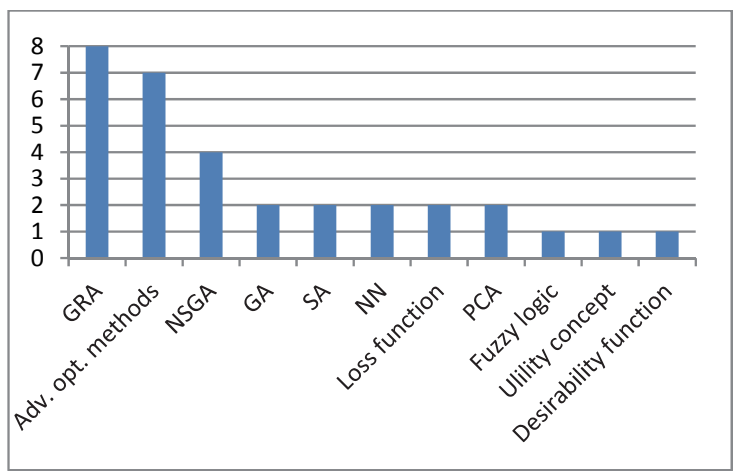

(c)

Fig. 6 Analysis on the parametric optimization of HM processes 


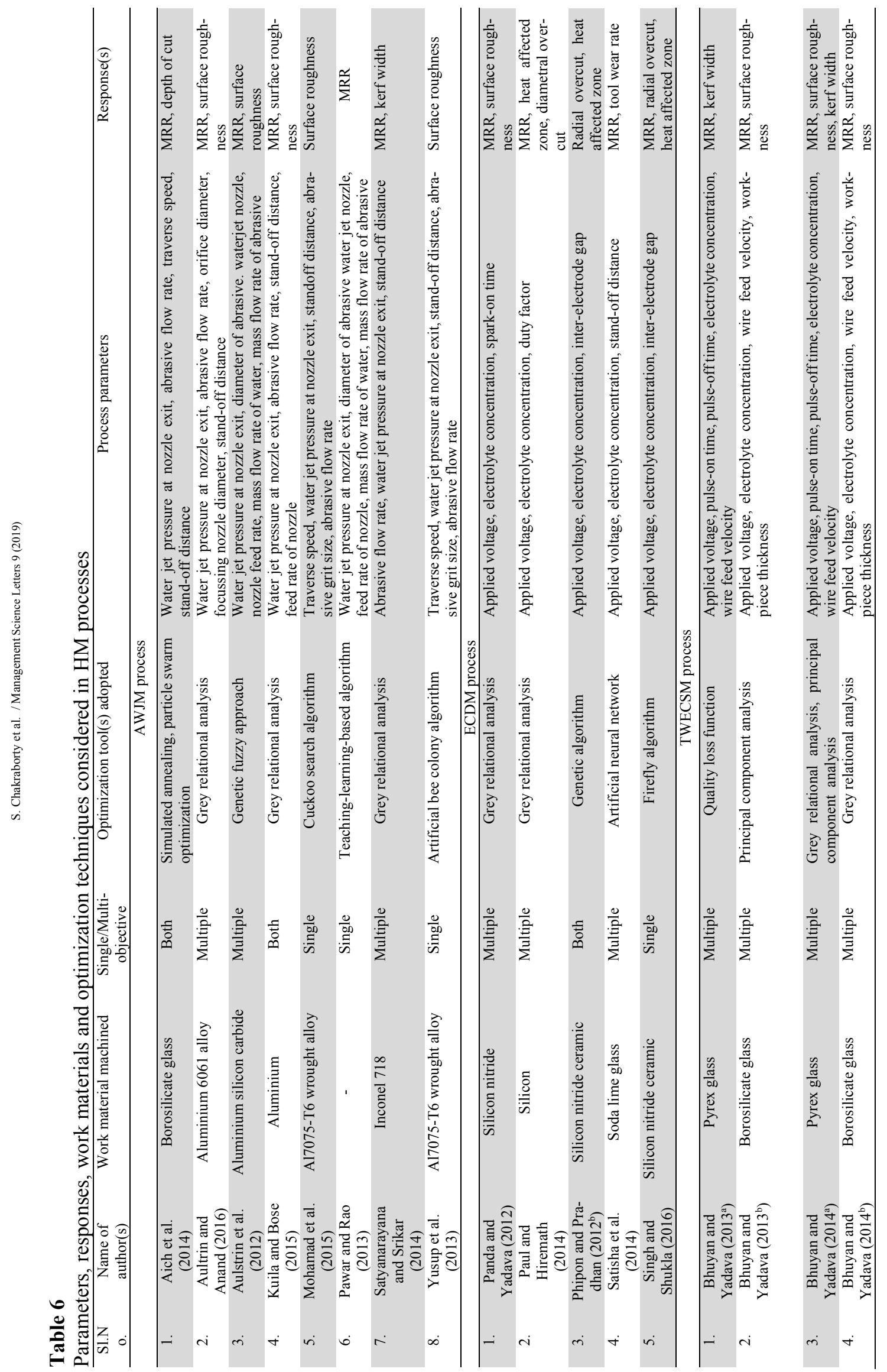




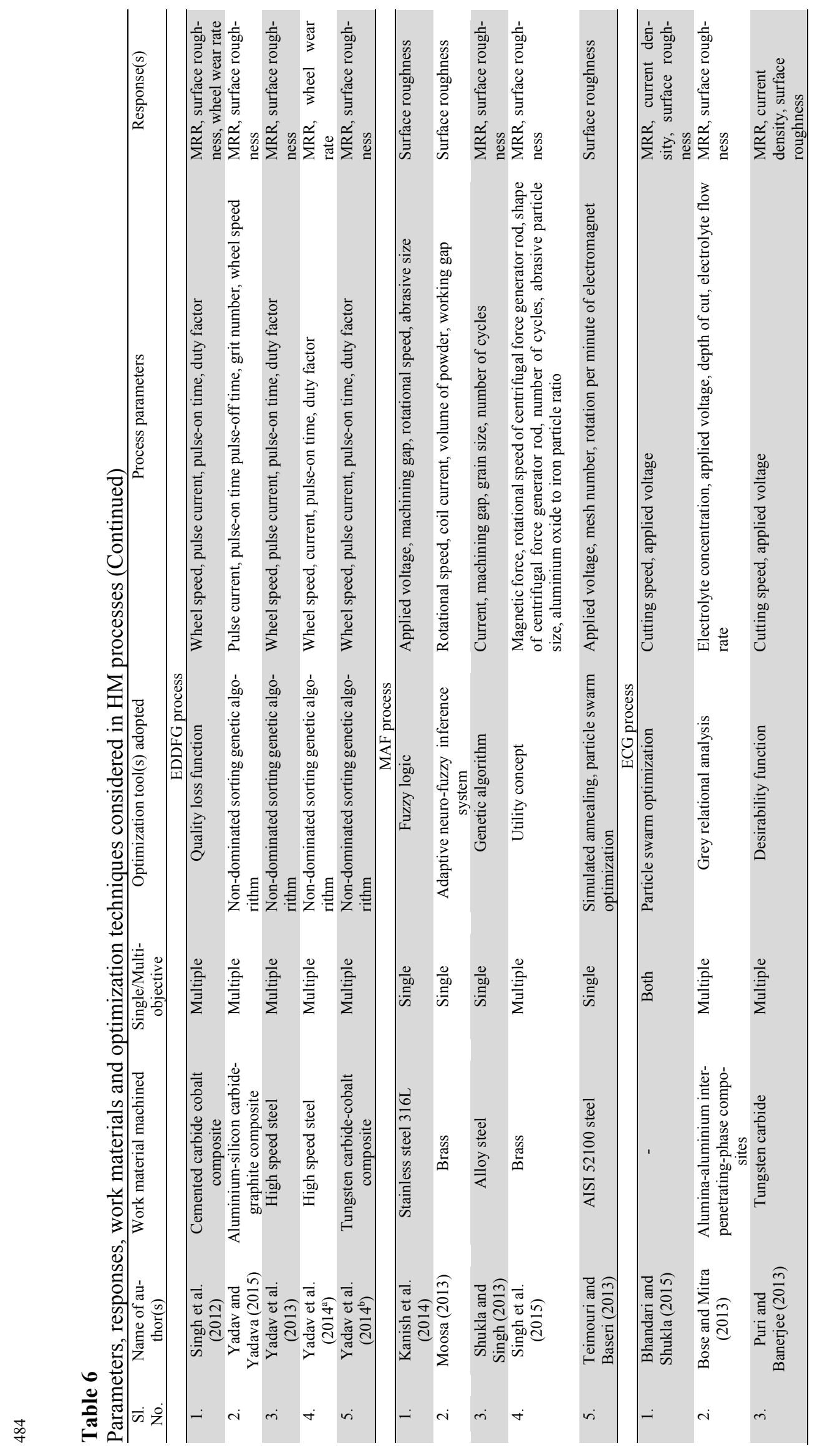




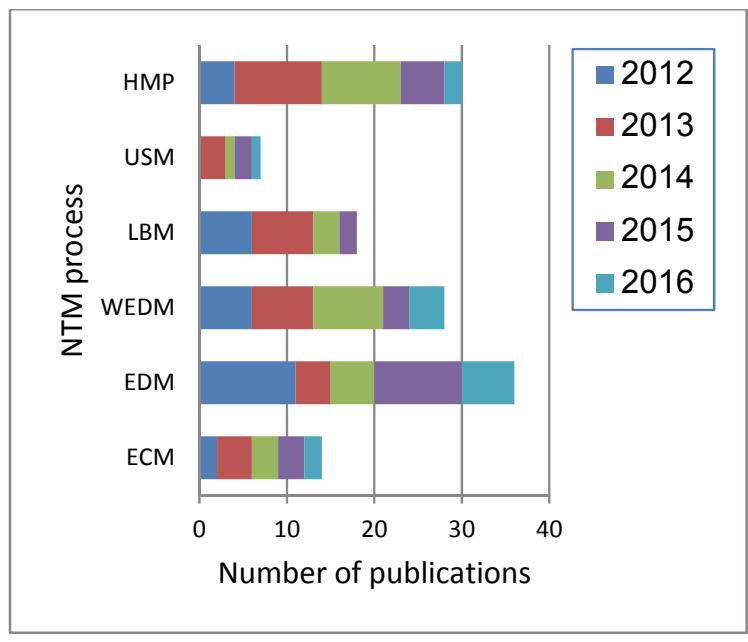

Fig. 7 Year-wise publication of research papers on parametric optimization of NTM processes

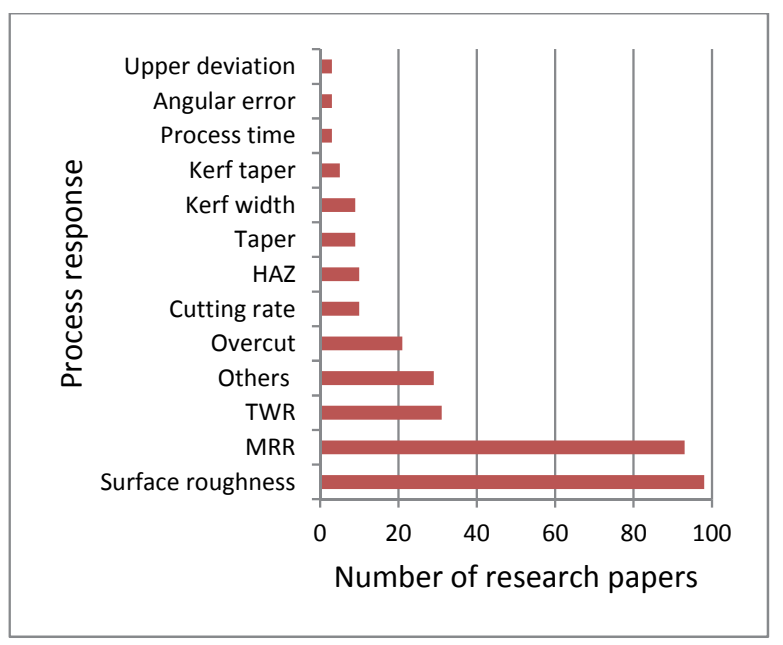

Fig. 8 Responses considered in the NTM processes

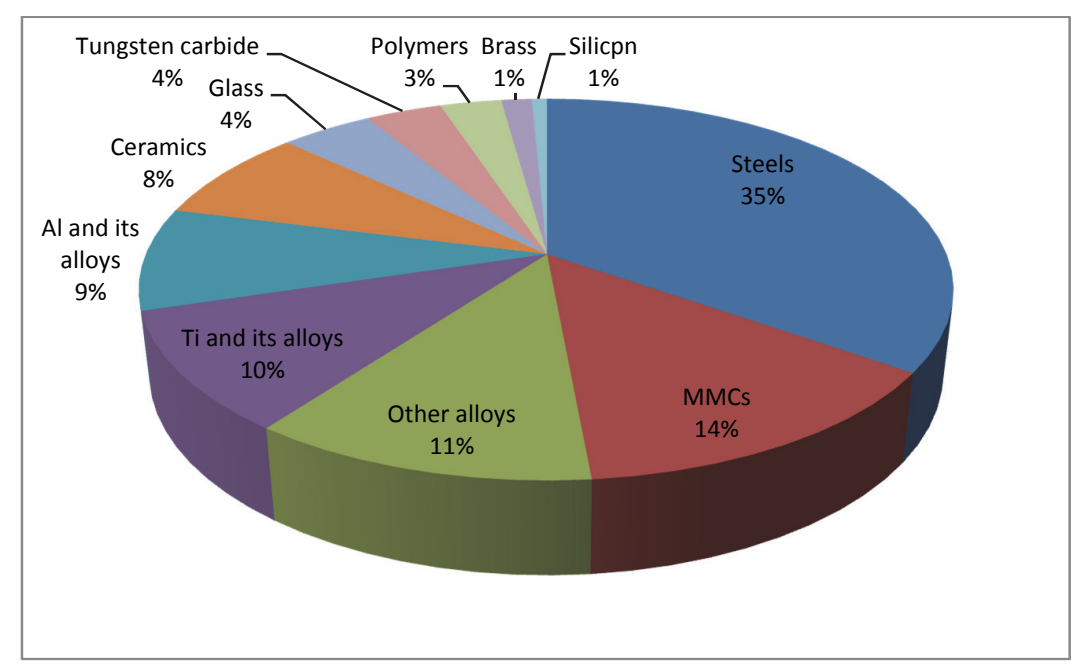

Fig. 9 Various work materials machined by NTM processes

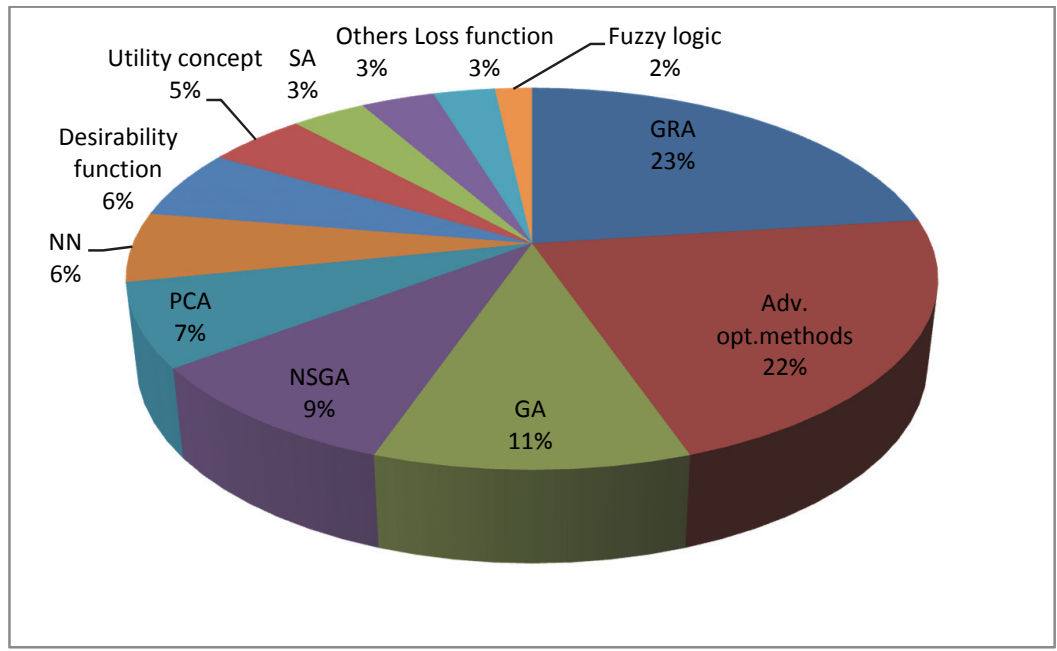

Fig. 10 Optimization tools adopted for parametric optimization of NTM processes 


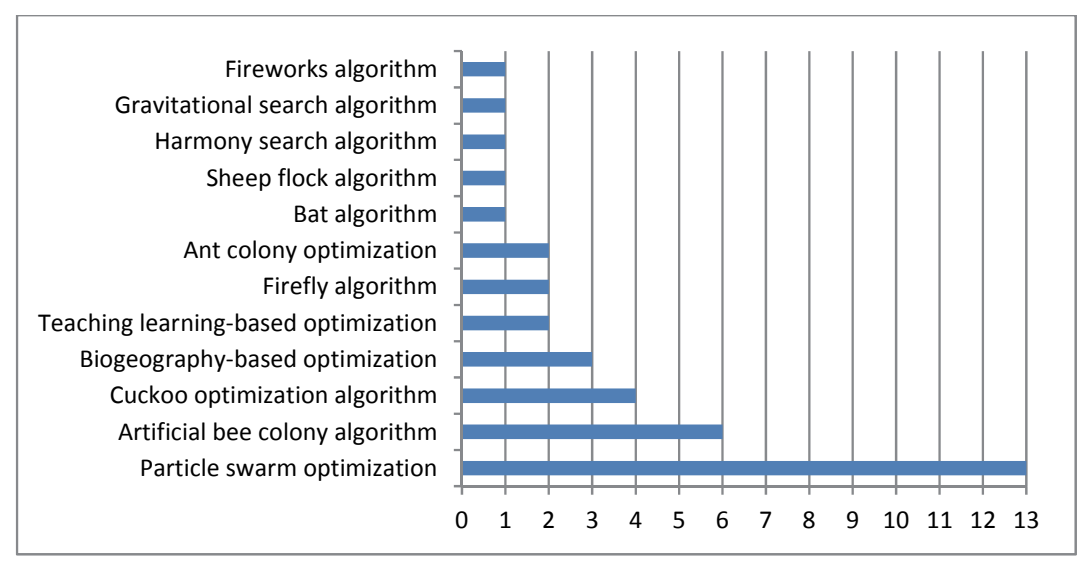

Fig. 11 Applications of different advanced optimization methods for parametric optimization of NTM processes

\section{Conclusions}

In this paper, 133 journal papers published during 2012-16 are reviewed in order to analyze the selected process parameters, observed responses, work materials machined and optimization techniques adopted for parametric optimization of six types of NTM processes. Based on this analysis, the following inferences can be put forward:

(a) EDM is the most popular NTM process (27.07\%), followed by HM process (22.56\%) and WEDM process $(21.05 \%)$. On the other hand, the researchers must pay more attention to explore the capabilities of ECM (10.53\%) and USM (5.26\%) processes for their successful industrial applications.

(b) On EDM process, maximum research work was carried out in 2012. Plenty of experimental works was also performed on the other considered NTM processes during 2014.

(c) The researchers maximally attempted to optimize surface roughness $(73.38 \%)$, followed by MRR (69.92\%) and TWR (23.31\%). There are several other responses which are less frequently considered for optimization depending on the machined shape geometry and end product requirements.

(d) Various grades of steel (mainly AISI and EN) and MMCs (primarily aluminium silicon/boron carbide) are the most popular work materials primarily machined by these NTM processes due to their huge demand for real time industrial applications. Aluminium and its alloys, titanium and its alloys, and other alloys (like Inconel, Rene, Invar etc.) are also machined using the considered NTM processes.

(e) With respect to the tools employed for parametric optimization of NTM processes, the past researchers maximally preferred GRA and other advanced optimization methods (like artificial bee colony algorithm, particle swarm optimization, cuckoo optimization algorithm etc.) as the most suitable techniques. When GA, NSGA and SA are coupled together with the advanced optimization methods, they have the maximum preference due to their ability to solve both single and multi-objective complex optimization problems with high solution accuracy and less computational time, while providing almost global optimal solutions.

(f) Among the adopted advanced optimization methods, particle swarm optimization has the maximum number of applications, followed by artificial bee colony and cuckoo optimization algorithms.

(g) Maximum research works are carried out on multi-objective optimization of NTM processes.

The detailed analysis of the reviewed papers would help the concerned process engineers in identifying the most appropriate NTM process for fulfilling the end product requirements, selecting the suitable process parameters and desired responses, and choosing the most appropriate optimization tool to determine the best parametric mix for achieving the maximum machining performance. From this review, it can be concluded that for parametric optimization of NTM processes, grey relational analysis and particle swarm optimization are the best suited techniques due to their numerous added advantages over the 
others. Although, these techniques were rightly applied for the said purpose, but the application potentiality of other almost new optimization techniques, like grey wolf algorithm, artificial algae algorithm, shuffled frog leaping algorithm, sine cosine algorithm etc. needs to be explored for their successful deployment for parametric optimization of NTM processes.

\section{References}

Abuzied, H.H., Awad, M.A., \& Senbel, H.A. (2012). Prediction of electrochemical machining process parameters using artificial neural networks. International Journal of Computer Science Engineering, 4(1), 125-132.

Acherjee, B., Prakash, S., Kuar, A. S., \& Mitra, S. (2014). Grey relational analysis based optimization of underwater Nd: YAG laser micro-channeling on PMMA. Procedia Engineering, 97, 1406-1415.

Aggarwal, V., Khangura, S.S., \& Garg, R.K. (2015). Parametric modeling and optimization for wire electrical discharge machining of Inconel 718 using response surface methodology. International Journal of Advanced Manufacturing Technology, 79(1-4), 31-47.

Aich, U., Banerjee, S., Bandyopadhyay, A., \& Das, P. K. (2014). Multi-objective optimisation of abrasive water jet machining responses by simulated annealing and particle swarm. International Journal of Mechatronics and Manufacturing Systems, 7(1), 38-59.

Aich, U., \& Banerjee, S. (2016). Application of teaching learning based optimization procedure for the development of SVM learned EDM process and its pseudo Pareto optimization. Applied Soft Computing, 39, 64-83.

Anitha, J., Das, R., \& Pradhan, M. K. (2016). Multi-objective optimization of electrical discharge machining processes using artificial neural network. Jordan Journal of Mechanical and Industrial Engineering, 10(1), 11-18.

Aultrin, K. J., \& Anand, M.D. (2016). Multi-objective optimization of abrasive water jet machining of aluminium 6061 alloy by grey relational analysis. Journal of Chemical and Pharmaceutical Sciences. 9(1), 410-417.

Aultrin, K. J., Anand, M.D., \& Jose, P. (2012). Modelling the cutting process and cutting performance in abrasive water jet machining using genetic-fuzzy approach. Procedia Engineering, 38, 4013-4020.

Ay, M., Çaydaş, U., \& Hascalik, A. (2013). Optimization of micro-EDM drilling of inconel 718 super alloy. International Journal of Advanced Manufacturing Technology, 66(5), 1015-1023.

Azhiri, R.B., Teimouri, R., Baboly, M.G., \& Leseman, Z. (2014). Application of Taguchi, ANFIS and grey relational analysis for studying, modelling and optimization of wire EDM process while using gaseous media. International Journal of Advanced Manufacturing Technology, 71(1-4), 279-295.

Baraskar, S.S., Banwait, S.S., \& Laroiya, S.C. (2013). Multi-objective optimization of electrical discharge machining process using a hybrid method. Journal of Materials and Manufacturing Processes, 28(4), 348-354.

Behera, S., Satapathy, S., \& Ghadai, S.K. (2015). Parameter optimisation of powder mixed EDM of aluminium-based metal matrix composite using Taguchi and grey analysis. International Journal Productivity and Quality Management, 16(2), 148-168.

Bhandari, S., \& Shukla, N. (2015). Parametric optimization of electrochemical grinding operation by particle swarm optimization technique. SSRG International Journal of Mechanical Engineering, 2(4), 1-6.

Bharti, P.S., Maheshwari, S., \& Sharma, C. (2012). Multi-objective optimization of electric-discharge machining process using controlled elitist NSGA-II. Journal of Mechanical Science and Technology, 26(6), $1875-1883$.

Bhattacharyya, B., Munda, J., \& Malapati, M. (2004). Advancement in electrochemical micro-machining. International Journal of Machine Tools \& Manufacture, 44(15), 1577-1589.

Bhavsar, S. N., Aravindan, S., \& Rao, P. V. (2015). Investigating material removal rate and surface roughness using multi-objective optimization for focused ion beam (FIB) micro-milling of cemented carbide. Precision Engineering, 40, 131-138.

Bhuyan, B. K., \& Yadava, V. $\left(2013^{\mathrm{a}}\right)$. Experimental modeling and multi-objective optimization of traveling wire electrochemical spark machining (TW-ECSM) process. Journal of Mechanical Science and Technology, 27(8), 2467-2476. 
Bhuyan, B. K., \& Yadava, V. $\left(2013^{\mathrm{b}}\right)$. Simultaneous optimization of multiple quality characteristics in travelling wire electrochemical spark machining of pyrex glass. Asian Journal of Engineering and Applied Technology, 2(2), 19-24.

Bhuyan, B. K., \& Yadava, V. (2014 ). Experimental modelling and multi-response optimization of travelling wire electrochemical spark machining of pyrex glass. Proceedings of the Institution of Mechanical Engineers, Part B: Journal of Engineering Manufacture, 228(8), 902-916.

Bhuyan, B. K., \& Yadava, V. (2014 $)$. Modelling and optimisation of travelling wire electro-chemical spark machining process. International Journal of Industrial and Systems Engineering, 18(2), 139-158.

Boopathi, S., \& Sivakumar, K. (2013). Experimental investigation and parameter optimization of near-dry wire-cut electrical discharge machining using multi-objective evolutionary algorithm. International Journal of Advanced Manufacturing Technology, 67(9-12), 2639-2655.

Boopathi, S., \& Sivakumar, K. (2016). Optimal parameter prediction of oxygen-mist near-dry wire-cut EDM. International Journal of Manufacturing Technology and Management, 30(3-4), 164-178.

Bose, G.K., \& Mitra, S. (2013). Study of ECG process while machining $\mathrm{Al}_{2} \mathrm{O}_{3} / \mathrm{Al}$-IPC using grey-Taguchi methodology. Advances in Production Engineering \& Management, 8(1), 41-51.

Chakravorty, R., Gauri S.K., \& Chakraborty, S. (2012). Optimization of correlated responses of EDM process. Journal of Materials and Manufacturing Processes, 27(3), 337-347.

Chakravorty, R., Gauri, S., \& Chakraborty, S. (2013). Optimization of multiple responses of ultrasonic machining (USM) process: A comparative study. International Journal of Industrial Engineering Computations, 4(2), 285-296.

Chalisgaonkar, R., \& Kumar, J. (2013). Optimization of WEDM process of pure titanium with multiple performance characteristics using Taguchi's DOE approach and utility concept. Frontiers of Mechanical Engineering, 8(2), 201-214.

Cheema, M. S., Dvivedi, A., \& Sharma, A. K. (2013). A hybrid approach to multi-criteria optimization based on user's preference rating. Proceedings of the Institution of Mechanical Engineers, Part B: Journal of Engineering Manufacture, 227(11), 1733-1742.

Das, S., Doloi, B., \& Bhattacharyya, B. (2013). Optimisation of ultrasonic machining of zirconia bio-ceramics using genetic algorithm. International Journal of Manufacturing Technology and Management, 27(4-6), 186-197.

Dave, H.K., Desai, K.P., \& Raval, H.K. (2012). Optimisation of multiple response characteristics in orbital electro discharge machining of Inconel 718 using Taguchi's loss function. International Journal of Manufacturing Technology and Management, 25(1-3), 78-94.

Dewangan, S., \& Biswas, C.K. (2013). Optimisation of machining parameters using grey relation analysis for EDM with impulse flushing. International Journal Mechatronics and Manufacturing Systems, 6(2), 144158.

Dewangan, S., Gangopadhyay, S., \& Biswas, C.K. (2015). Multi-response optimization of surface integrity characteristics of EDM process using grey-fuzzy logic-based hybrid approach. International Journal of Engineering Science and Technology, 18(3), 361-368.

Dhobe, S.H., Doloi, B. \& Bhattacharya B. (2014). Optimisation of ECM process during machining of titanium using quality loss function. International Journal of Manufacturing Technology and Management, 28(13), 19-38.

Dubey, A.K., \& Yadava, V. (2008). Laser beam machining - A review. International Journal of Machine Tools \& Manufacture, 48(6), 609-628.

El-Hofy, H. (2005). Advanced machining processes : Nontraditional and hybrid machining processes. McGraw-Hill, New York.

Ganguly, D., Acherjee, B., Kuar, A. S., \& Mitra, S. (2012). Hole characteristics optimization in Nd: YAG laser micro-drilling of zirconium oxide by grey relation analysis. International Journal of Advanced Manufacturing Technology, 61(9-12), 1255-1262.

Garg, M.P., Jain, A., \& Bhushan, G. (2012). Modelling and multi-objective optimization of process parameters of wire electrical discharge machining using non-dominated sorting genetic algorithm-II. Proceedings of the Institution of Mechanical Engineers, Part B: Journal of Engineering Manufacture, 226(12), 1986-2001. 
Golshan, A., Gohari, S., \& Ayob, A. (2012). Multi-objective optimisation of electrical discharge machining of metal matrix composite $\mathrm{Al} / \mathrm{SiC}$ using non-dominated sorting genetic algorithm. International Journal of Mechatronics and Manufacturing Systems, 5(5-6), 385-398.

Gopal, A. \& Chakradhar, D. (2012). Parametric optimization in electrochemical machining of EN31 steel based on grey relation approach. International Journal of Applied Mechanics and Material, 110, 16491656.

Goswami, R. N., Mitra, S., \& Sarkar, S. (2009). Experimental investigation on electrochemical grinding (ECG) of alumina-aluminum interpenetrating phase composite. International Journal of Advanced Manufacturing Technology, 40(7), 729-741.

Goswami, D., \& Chakraborty, S. (2015). Parametric optimization of ultrasonic machining process using gravitational search and fireworks algorithms. Ain Shams Engineering Journal, 6(1), 315-331.

Ho, K.H., \& Newman, S.T. (2003). State of the art electrical discharge machining (EDM). International Journal of Machine Tools \& Manufacture, 43(13), 1287-1300.

Ho, K.H., Newman, S.T., Rahimifard, S., \& Allen, R.D. (2004). State of the art in wire electrical discharge machining (WEDM). International Journal of Machine Tools \& Manufacture, 44(12-13), 1247-1259.

Jagadish., \& Ray, A. (2015). Multi-objective optimization of green EDM: An integrated theory. Journal of the Institution of Engineers (India): Series C, 96(1), 41-47.

Janković, P., Igić, T., \& Nikodijević, D. (2012). Process parameters effect on material removal mechanism and cut quality of abrasive water jet machining. Theoretical and Applied Mechanics, 40(S1), 277-291.

Jayadithya, R., Deekshith, B., Chaithnya, P.L., \& Rajyalakshmi, G. (2014). Multi objective optimization of WEDM through Taguchi method and utility concept. International Journal of Science and Applied Information Technology, 3(4), 1-6.

Jegan, T.C.M., Ravindran, D., Dev Anand, M., \& Rohit, I.J. (2013). ECM parameters modeling and optimization using WSGA. Applied Mechanics and Materials, 423-426, 925-930.

Kalaimathi, M., Venkatachalam, G., \& Sivakumar, M. (2014). Experimental investigations on the electrochemical machining characteristics of monel 400 alloys and optimization of process parameters. Jordan Journal of Mechanical and Industrial Engineering, 8(3), 143-151.

Kanish, T.C., Kuppan, P., Narayanan, S., \& Ashok, S.D. (2014). A fuzzy logic based model to predict the improvement in surface roughness in magnetic field assisted abrasive finishing. Procedia Engineering, 97, 1948-1956.

Kataria, R., Kumar, J., \& Pabla, B.S. (2016). Experimental investigation and optimization of machining characteristics in ultrasonic machining of WC-Co composite using GRA method. Materials and Manufacturing Processes, 31(5), 685-693.

Kibria, G., Doloi, B., \& Bhattacharyya, B. (2013). Experimental investigation and multi-objective optimization of Nd: YAG laser micro-turning process of alumina ceramic using orthogonal array and grey relational analysis. Optics \& Laser Technology, 48, 16-27.

Kovačević, M., Madić, M., Radovanović, M., \& Rančić, D. (2014). Software prototype for solving multiobjective machining optimization problems: Application in non-traditional machining processes. Expert Systems with Applications, 41(13), 5657-5668.

Krishnan, S.A., \& Samuel, G.L. (2013). Multi-objective optimization of material removal rate and surface roughness in wire electrical discharge turning. International Journal of Advanced Manufacturing Technology, 67(9-12), 2021-2032.

Kuar, A.S., Acherjee, B., Ganguly, D., \& Mitra, S. (2012). Optimization of Nd: YAG laser parameters for microdrilling of alumina with multiquality characteristics via grey-Taguchi method. Materials and Manufacturing Processes, 27(3), 329-336.

Kuila, S. K., \& Bose, G. K. (2015). Process parameters optimization of aluminium by grey-Taguchi methodology during AWJM process. International Journal of Innovation Research in Science, Engineering and Technology, 4(9), 124-131.

Kumar, K., \& Agarwal, S. (2012). Multi-objective parametric optimization on machining with wire electric discharge machining. International Journal of Advanced Manufacturing Technology, 62(5-8), 617-633.

Kumar, H., Singh, S., \& Kumar, P. (2013). Magnetic abrasive finishing - A review. International Journal of Engineering Research \& Technology, 2(3), 1-9. 
Kumar, J. (2014). Investigations into the surface quality and micro-hardness in the ultrasonic machining of titanium (ASTM GRADE-1). Journal of the Brazilian Society of Mechanical Sciences and Engineering, 36(4), 807-823.

Kuriachen, B., Somashekhar, K.P., \& Mathew, J. (2015). Multiresponse optimization of micro-wire electrical discharge machining process. International Journal of Advanced Manufacturing Technology, 76(1-4), 91-104.

Madic, M., Petkovic, D., \& Radovanovic, M. (2014). GRA approach for multi-objective optimization of laser cutting. UPB Scientific Bulletin, Series B: Chemical and Material Science, 76(3), 169-180.

Madic, M., Radovanovic, M., Trajanovic, M., \& Manic, M. (2015). Multi objective optimization of laser cutting using cuckoo search algorithm. Journal of Engineering Science and Technology, 10(3), 353-363.

Majumder, A. (2012). Parametric optimization of electric discharge machining by GA-based response surface methodology. Journal for Manufacturing Science and Production, 12(1), 25-30.

Majumder, A. (2013). Process parameter optimization during EDM of AISI 316 LN stainless steel by using fuzzy based multi-objective PSO. Journal of Mechanical Science and Technology, 27(7), 2143-2151.

Majumder, A., Das P.K., Majumder, A., \& Debnath, M. (2014). An approach to optimize the EDM process parameters using desirability-based multi-objective PSO. Journal of Production and Manufacturing Research, 2(1), 228-240.

Majumder, A. (2015). Comparative study of three evolutionary algorithms coupled with neural network model for optimization of electric discharge machining process parameters. Proceedings of the Institution of Mechanical Engineers, Part B: Journal of Engineering Manufacture, 229(9), 1504-1516.

Malik, A., \& Manna, A. (2017). Travelling wire electrochemical spark machining: An overview. In: Nontraditional micromachining processes. Eds. Kibria, G., Bhattacharyya, B., \& Davim, J.P., Springer International Publishing.

Manikandan, N., Kumanan, S., \& Sathiyanarayanan, C. (2015). Multi-response optimization of titanium Ti6Al-4V alloy using Taguchi based grey relational analysis. Indian Journal of Engineering and Material Sciences, 22(2), 153-160.

Mediliyegedara, T.K.K.R., De Silva, A.K.M., Harrison, D.K., \& McGeough, J.A. (2005). New developments in the process control of the hybrid electro chemical discharge machining (ECDM) process. Journal of Materials Processing Technology, 167(2-3), 338-343.

Meijer, J. (2004). Laser beam machining (LBM), state of the art and new opportunities. Journal of Materials Processing Technology, 149(1-3), 2-17.

Ming, W., Zhang, Z., Zhang, G., Huang, Y., Guo, J., \& Chen, Y. (2014). Multi-objective optimization of 3Dsurface topography of machining YG15 in WEDM. Materials and Manufacturing Processes, 29(5), 514525.

Ming, W., Ma, J., Zhang, Z., Huang, H., Shen, D., Zhang, G., \& Huang, Y. (2016). Soft computing models and intelligent optimization system in electro-discharge machining of $\mathrm{SiC} / \mathrm{Al}$ composites. International Journal of Advanced Manufacturing Technology, 87(1), 201-217.

Mishra, S., \& Yadava, V. (2013 $)$. Modeling and optimization of laser beam percussion drilling of nickelbased superalloy sheet using Nd: YAG laser. Optics and Lasers in Engineering, 51(6), 681-695.

Mishra, S., \& Yadava, V. $\left(2013^{\mathrm{b}}\right)$. Modeling and optimization of laser beam percussion drilling of thin aluminium sheet. Optics \& Laser Technology, 48, 461-474.

Moghaddam, M.A., Kolahan, F. (2015). Optimization of EDM process parameters using statistical analysis and simulated annealing algorithm. International Journal of Engineering, 28(1), 154-163.

Mohamad, A., Zain, A. M., Bazin, N. E. N., \& Udin, A. (2015). A process prediction model based on cuckoo algorithm for abrasive waterjet machining. Journal of Intelligent Manufacturing, 26(6), 1247-1252.

Mohanty, C.P., Mahapatra, S.S., \& Sahu, J. $\left(2016^{a}\right)$. Parametric optimisation of electrical discharge machining process: A numerical approach. International Journal of Industrial and Systems Engineering, 22(2), 207-244.

Mohanty, C.P., Mahapatra, S.S., \& Singh, M.R. $\left(2016^{\mathrm{b}}\right)$. A particle swarm approach for multi-objective optimization of electrical discharge machining process. Journal of Intelligent Manufacturing, 27(6), 11711190.

Moosa, A. A. (2013). Utilizing a magnetic abrasive finishing technique (MAF) via adaptive neuro fuzzy (ANFIS). American Journal of Materials Engineering and Technology, 1(3), 49-53. 
Mukherjee, R., \& Chakraborty, S. (2012). Selection of EDM process parameters using biogeography-based optimization algorithm. Journal of Materials and Manufacturing Processes, 27(9), 954-962.

Mukherjee, R., Chakraborty, S., \& Samanta, S. (2012). Selection of wire electrical discharge machining process parameters using non-traditional optimization algorithms. Applied Soft Computing, 12(8), 2506-2516.

Mukherjee, R., \& Chakraborty, S. (2013). Selection of the optimal electrochemical machining process parameters using biogeography-based optimization algorithm. International Journal of Advanced Manufacturing and Technology, 64(5), 781-791.

Mukherjee, R., Goswami, D., \& Chakraborty, S. (2013). Parametric optimization of Nd: YAG laser beam machining process using artificial bee colony algorithm. Journal of Industrial Engineering, http://dx.doi.org/10.1155/2013/570250.

Nayak, B.B., \& Mahapatra, S.S. (2014). A utility concept approach for multi-objective optimization of taper cutting operation using WEDM. Procedia Engineering, 97, 469-478.

Nayak, B.B., \& Mahapatra, S.S. (2016). Optimization of WEDM process parameters using deep cryo-treated inconel 718 as work material. International Journal of Engineering Science and Technology, 19(1), 161170.

Padhee, S., Nayak, N., Panda, S.K., Dhal, P.R., \& Mahapatra, S.S. (2012). Multi-objective parametric optimization of powder mixed electro-discharge machining using response surface methodology and nondominated sorting genetic algorithm. Proceedings of Indian Academy of Sciences (Sadhana), 32(2), 223240.

Panda, M. C., \& Yadava, V. (2012). Intelligent modeling and multiobjective optimization of die sinking electrochemical spark machining process. Materials and Manufacturing Processes, 27(1), 10-25.

Panda, S., Mishra, D, Biswal, B.B., \& Nanda, P. (2015). Optimization of multiple response characteristics of EDM process using Taguchi-based grey relational analysis and modified PSO. Journal of Advanced Manufacturing Systems, 14(3), 123-148.

Pandey, A. K., \& Dubey, A. K. $\left(2012^{\mathrm{a}}\right)$. Simultaneous optimization of multiple quality characteristics in laser cutting of titanium alloy sheet. Optics \& Laser Technology, 44(6), 1858-1865.

Pandey, A. K., \& Dubey, A. K. $\left(2012^{b}\right)$. Taguchi based fuzzy logic optimization of multiple quality characteristics in laser cutting of Duralumin sheet. Optics and Lasers in Engineering, 50(3), 328-335.

Pandey, A. K., \& Dubey, A. K. (2013). Multiple quality optimization in laser cutting of difficult-to-laser-cut material using grey-fuzzy methodology. International Journal of Advanced Manufacturing Technology, 65(1-4), 421-431.

Paul, L., \& Hiremath, S. S. (2014). Evaluation of process parameters of ECDM using grey relational analysis. Procedia Materials Science, 5, 2273-2282.

Pawar, P. J., \& Rao, R. V. (2013). Parameter optimization of machining processes using teaching-learningbased optimization algorithm. International Journal of Advanced Manufacturing Technology, 67(5-8), 995-1006.

Pawar, P. J., \& Rayate, G. B. (2014). Multi-objective optimization of laser beam machining process parameters. International Journal of Advanced Mechanical Engineering, 4(3), 257-262.

Phipon, R., \& Pradhan, B. B. $\left(2012^{\mathrm{a}}\right)$. Control parameters optimization of laser beam machining using genetic algorithm. International Journal of Computational Engineering Research, 2(5), 1510-1516.

Phipon, R., \& Pradhan, B. B. $\left(2012^{\mathrm{b}}\right)$. Optimization of electro-chemical discharge machining process using genetic algorithm. IOSR Journal of Engineering, 2(9), 106-115.

Porwal, R.K., Yadava, R.K., \& Ramkumar, J. (2012). Artificial neural network modelling and multi-objective optimisation of hole drilling electro discharge micro machining of invar. International Journal of Mechatronics and Manufacturing Systems, 5(5-6), 470-492.

Pradhan, M. K. (2012). Determination of optimal parameters with multi-response characteristics of EDM by response surface methodology, grey relational analysis and principal component analysis. International Journal of Manufacturing Technology and Management, 26(1-4), 56-80.

Prasad, D.V.S.S.S.V., \& Krishna, A.G. (2015). Empirical modelling and optimization of kerf and wire wear ratio in wire electrical discharge machining. International Journal of Advanced Manufacturing Technology, 77(1-4), 427-441.

Priyadarshini, M., \& Pal, K. (2016). Multi-objective optimisation of EDM process using hybrid Taguchibased methodologies for Ti-6Al-4V alloy. International Journal of Manufacturing Research, 11(2), 144166. 
Puri, A. B., \& Banerjee, S. (2013). Multiple-response optimisation of electrochemical grinding characteristics through response surface methodology. International Journal of Advanced Manufacturing Technology, 64(5-8), 715-725.

Radhika, N., Chandran, G.K., Shivaram, P., \& Karthik, K.T. (2015). Multi-objective optimization of EDM parameters using grey relation analysis. Journal of Engineering Science and Technology, 10(1), 1-11.

Raja, S. B., Pramod C.V. K., Krishna, K. V., Ragunathan, A., \& Vinesh, S. (2015). Optimization of electrical discharge machining parameters on hardened die steel using firefly algorithm. Journal of Engineering with Computers, 31(1), 1-9.

Rajurkar, K.P., Zhu, D., McGeough, J.A., Kozak, J., \& De Silva, A. (1999). New developments in electrochemical machining. Annals of the ClRP, 48(2), 567-579.

Rajyalakshmi, G., \& Ramaiah, P.V. (2013). Multiple process parameter optimization of wire electrical discharge machining on Inconel 825 using Taguchi grey relational analysis. International Journal of Advanced Manufacturing Technology, 69(5-8), 1249-1262.

Rao, P.S., Ramji, K., \& Satyanarayana, B. (2014). Experimental investigation and optimization of wire EDM parameters for surface roughness, MRR and white layer in machining of aluminium alloy. Procedia Materials Science, 5, 2197-2206.

Rao, T.B., \& Krishna, A.G. (2014). Selection of optimal process parameters in WEDM while machining Al7075/SiCp metal matrix composites. International Journal of Advanced Manufacturing Technology, 73(1-4), 299-314.

Rao, S.M., \& Padmanabham, G. (2015). Parametric optimization in electrochemical machining using utility based Taguchi method. Journal of Engineering Science and Technology, 10(1), 81-96.

Rathod, P., Aravindan, S., \& Rao, P. V. (2015). Parametric optimization during dry machining of titanium alloy (Ti6A14V) with innovative textured tools for optimum product quality. International Journal of Engineering Development and Research, 4(3), 1067-1074.

Saha, A., \& Mondal, S.C. (2016). Multi-objective optimization in WEDM process of nanostructured hardfacing materials through hybrid techniques. Measurement, 94, 46-59.

Saha, P., Tarafdar, D., Pal, S. K., Saha, P., Srivastava, A.K., \& Das, K. (2013). Multi-objective optimization in wire-electro-discharge machining of $\mathrm{TiC}$ reinforced composite through neuro-genetic technique. Applied Soft Computing, 13(4), 2065-2074.

Sahu, S.N., \& Nayak, N.C. (2015). Multi-objective optimization of EDM process: RSM modelling and genetic algorithm approach. Journal of Production Engineering, 18(2), 29-32.

Sathisha, N., Hiremath, S. S., \& Shivakumar, J. (2014). Prediction of material removal rate using regression analysis and artificial neural network of ECDM process. International Journal of Recent Advances in Mechanical Engineering, 3(2), 69-81.

Sathiyamoorthy, V., Sekar, T., \& Elango, N. (2015). Optimization of processing parameters in ECM of die tool steel using nanofluid by multi-objective genetic algorithm. The Scientific World Journal, http://dx.doi.org/10.1155/2015/895696.

Sathiyamoorthy, V., \& Sekar, T. (2016). Optimisation of processing parameters in ECM of AISI 202 using multi objective genetic algorithm. International Journal of Enterprise Network Management, 7(2), 133141.

Satyanarayana, B., \& Srikar, G. (2014). Optimization of abrasive water jet machining process parameters using Taguchi grey relational analysis. International Journal of Mechanical and Production Engineering, 2(9), 82-87.

Senthilkumar, C., Ganesan, G., \& Karthikeyan, R. (2013). Influence of input parameters on characteristics of electro chemical machining process. International Journal of Applied Science and Engineering, 11(1), 1324.

Shahali, H., Yazdi, M.R.S., Mohammadi, A., \&Iimanian, E. (2012). Optimization of surface roughness and thickness of white layer in wire electrical discharge machining of DIN 1.4542 stainless steel using microgenetic algorithm and signal to noise ratio techniques. Proceedings of the Institution of Mechanical Engineers, Part B: Journal of Engineering Manufacture, 226(5), 803-812.

Sharma, A., \& Yadava, V. (2012). Modelling and optimization of cut quality during pulsed Nd: YAG laser cutting of thin Al-alloy sheet for straight profile. Optics \& Laser Technology, 44(1), 159-168.

Sharma, A., \& Yadava, V. (2013). Modelling and optimization of cut quality during pulsed Nd: YAG laser cutting of thin Al-alloy sheet for curved profile. Optics and Lasers in Engineering, 51(1), 77-88. 
Shayan, A.V., Afza, R.A., \& Teimouri, R. (2013). Parametric study along with selection of optimal solutions in dry wire cut machining of cemented tungsten carbide (WC-Co). Journal of Manufacturing Processes, 15(4), 644-658.

Shukla, A., \& Singh, D. K. (2013). Modelling and optimization of magnetic abrasive finishing process. International Journal of Engineering Research and Technology, 2(9), 1471-1478.

Singh, S. (2012). Optimization of machining characteristics in electric discharge machining of $6061 \mathrm{Al} / \mathrm{Al}_{2} \mathrm{O}_{3} \mathrm{p} / 20 \mathrm{P}$ composites by grey relational analysis. International Journal of Advanced Manufacturing Technology, 63(9), 1191-1202.

Singh, G. K., Yadava, V., \& Kumar, R. (2012). Modelling and optimisation of electro-discharge diamond face grinding of cemented carbide-cobalt composite. International Journal of Industrial and Systems Engineering, 12(2), 141-164.

Singh, R., Walia, R. S., \& Suri, N. M. (2015). Parametric optimization of centrifugal-magnetic force assisted abrasive flow machining process using utility concept. International Journal of Research in Engineering and Technology, 4(8), 382-388.

Singh, D., \& Shukla, R. S. (2016). Optimisation of electrochemical micromachining and electrochemical discharge machining process parameters using firefly algorithm. International. Journal of Mechatronics and Manufacturing Systems, 9(2), 137-159.

Sohrabpoor, H., Khanghah, S.P., Shahraki, S., \& Teimouri, R. (2016). Multi-objective optimization of electrochemical machining process. International Journal of Advanced Manufacturing Technology, 82(9), $1683-1692$.

Solaiyappan, A., Kalaimathi, M., \& Venkatachalam, G. (2014). Multi-objective optimization of process pa-

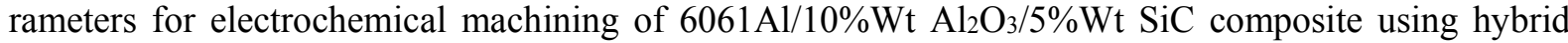
fuzzy-artificial bee colony algorithm. Jordan Journal of Mechanical and Industrial Engineering, 8(5), 323-331.

Somashekhar, K.P., Mathew, J., \& Ramachandran, N. (2012). A feasibility approach by simulated annealing on optimization of micro-wire electric discharge machining parameters. International Journal of Advanced Manufacturing Technology, 61(9-12), 1209-1213.

Subrahmanyam, S.V., \& Sarcar, M.M.M. (2013). Evaluation of optimal parameters for machining with wire cut EDM using Grey-Taguchi method. International Journal of Scientific and Research Publications, 3(3), 1-9.

Sundaram, M. M. (2014). Hybrid machining processes. In Nee, A.Y.C. (Ed.) Handbook of Manufacturing Engineering and Technology, 1109-1126.

Tamrin, K. F., Nukman, Y., Choudhury, I. A., \& Shirley, S. (2015). Multiple-objective optimization in precision laser cutting of different thermoplastics. Optics and Lasers in Engineering, 67, 57-65.

Tang, L., \& Yang, S. (2013). Experimental investigation on the electrochemical machining of $00 \mathrm{Cr} 12 \mathrm{Ni} 9 \mathrm{Mo} 4 \mathrm{Cu} 2$ material and multi-objective parameters optimization. International Journal of Advanced Manufacturing Technology, 67(9), 2909-2916.

Tang, L., \& Du, Y.T. (2014). Multi-objective optimization of green electrical discharge machining Ti-6Al$4 \mathrm{~V}$ in tap water via grey-Taguchi method. Journal of Materials and Manufacturing Processes, 29(5), 507-513.

Teimouri, R., \& Baseri, H. (2012). Improvement of dry EDM process characteristics using artificial soft computing methodologies. Journal of Production Engineering Research and Development, 6(4), 493-504.

Teimouri, R., \& Baseri, H. (2013). Artificial evolutionary approaches to produce smoother surface in magnetic abrasive finishing of hardened AISI 52100 steel. Journal of Mechanical Science and Technology, 27(2), 533-539.

Teimouri, R., \& Baseri, H. (2014). Optimization of magnetic field assisted EDM using the continuous ACO algorithm. Applied Soft Computing, 14, 381-389.

Teimoiri, R., \& Shorabpoor, H. (2013). Application of adaptive neuro-fuzzy inference system and cuckoo optimization algorithm for analyzing electrochemical machining process. Frontiers of Mechanical Engineering, 8(4), 429-442.

Teimouri, R., Baseri, H., \& Moharami, R. (2015). Multi-responses optimization of ultrasonic machining process. Journal of Intelligent Manufacturing, 26(4), 745-753. 
Teixidor, D., Ferrer, I., Ciurana, J., \& Ozel, T. (2013). Optimization of process parameters for pulsed laser milling of micro-channels on AISI H13 tool steel. Robotics and Computer-Integrated Manufacturing, 29(1), 209-218.

Thangadurai, K.R., \& Asha, A. (2014). Parametric optimization of EDM process of aluminium boron carbide composite using desirability function approach and genetic algorithm. Journal of Applied Mechanics and Materials, 592-594, 684-688.

Thoe, T.B., Aspinwall, D.K., \& Wise, M.L.H. (1998). Review on ultrasonic machining. International Journal of Machine Tools \& Manufacture, 38(4), 239-255.

Uyyala, S.B., \& Kumar, A. (2014). Performance analysis of electrical discharge machining parameters on RENE 80 nickel super alloy using statistical tools. International Journal of Machining and Machinability of Materials, 15(3-4), 212-234.

Varun, S., Rajyalakshmi, G., Reddy, B.B., \& Reddy, R.R.V.V. (2016). Modelling and multi objective optimization of WEDM of commercially monel super alloy using evolutionary algorithms. IOP Conference Series: Materials Science and Engineering, 149(1), 1-15.

Yadav, R. N., Yadava, V., \& Singh, G.K. (2012). Intelligent modeling of electro-discharge diamond face grinding (EDDFG). International Journal of Surface Engineering \& Materials Technology, 2(2), 24-28.

Yadav, R. N., \& Yadava, V. (2015). Application of soft computing techniques for modelling and optimization of slotted-electrical discharge diamond face grinding process. Transactions of the Indian Institute of Metals, 68(5), 981-990.

Yadav, R. N., Yadava, V., \& Singh, G. K. (2013). Multi-objective optimization of process parameters in electro-discharge diamond face grinding based on ANN-NSGA-II hybrid technique. Frontiers of Mechanical Engineering, 8(3), 319-332.

Yadav, R. N., Yadava, V., \& Singh, G. K. (2014ª). Application of non-dominated sorting genetic algorithm for multi-objective optimization of electrical discharge diamond face grinding process. Journal of Mechanical Science and Technology, 28(6), 2299-2306.

Yadav, R. N., Yadava, V., \& Singh, G. K. (2014 $)$. Application of response surface methodology and genetic algorithm for optimisation of electro-discharge diamond face grinding of tungsten carbide-cobalt composite. International Journal of Industrial and Systems Engineering, 18(1), 76-94.

Yadav, U.S., \& Yadava, V. (2015). Experimental modelling and optimisation of process parameters of hole drilling by electrical discharge machining of aerospace titanium alloy. International Journal of Manufacturing Technology and Management, 29(3-4), 211-234.

Yang, R.T., Tzeng, C.J., Yang, Y.K., \& Hsieh, M.H. (2012). Optimization of wire electrical discharge machining process parameters for cutting tungsten. International Journal of Advanced Manufacturing Technology, 60(1-4), 135-147.

Yusup, N., Sarkheyli, A., Zain, A. M., Hashim, S. Z. M., \& Ithnin, N. (2014). Estimation of optimal machining control parameters using artificial bee colony. Journal of Intelligent Manufacturing, 25(6), 14631472 .

Zhang, G., Zhang, Z., Ming, W., Guo, J., Huang, Y., \& Shao, X. (2014). The multi-objective optimization of medium-speed WEDM process parameters for machining SKD11 steel by the hybrid method of RSM and NSGA-II. International Journal of Advanced Manufacturing Technology, 70(9), 2097-2109.

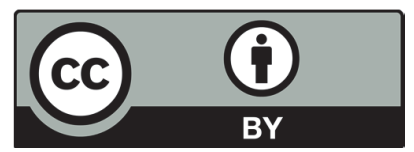

C 2019 by the authors; licensee Growing Science, Canada. This is an open access article distributed under the terms and conditions of the Creative Commons Attribution (CCBY) license (http://creativecommons.org/licenses/by/4.0/). 